\title{
Relative clauses in Upper Necaxa Totonac: Local, comparative, and diachronic perspectives ${ }^{1}$
}

\author{
David Beck \\ University of Alberta
}

Relativization strategies in the Totonacan family are largely undescribed, but detailed examination of one of the languages in the group, Upper Necaxa Totonac, reveals the presence of both externally-and internally-headed relative constructions. Also of note is the presence of relativizers that mark the animacy (human/non-human) of the head of the relative construction. This paper will show that, while phylogenetic evidence clearly demonstrates the relativizers to be descended diachronically from interrogative pronouns, they are best treated synchronically as complementizers, an analysis that follows directly from the presence of internally-headed relative constructions.

Totonacan languages are spoken by approximately 240,000 people (INEGI 2010) living in an area of east-central Mexico centred on northern Puebla State and including adjacent parts of Hidalgo and Veracruz (see Figure 1; languages dealt with directly in this paper are shown in red). The family is generally considered an isolate; however, recent work has suggested links to Mixe-Zoque (Brown et al. 2011) and Chitimacha (Brown et al. 2014). Although the family has only recently become the object of serious investigation and description, the focus has been largely on its (admittedly spectacular) morphology; little has been written about syntax, and even less about the structure of complex clauses. Relative clauses in particular seem to have been given short shrift - which is surprising, given that from what we do know about them they seem to have some unusual properties. Consider the example in (1) from Upper Necaxa Totonac, the language for which we currently have the most data on relativization: ${ }^{2}$

\footnotetext{
${ }^{1}$ I would like to thank my consultants in Patla and Chicontla, especially Porfirio Sampayo Macín and Longino Barragán Sampayo, for their help putting this paper together. I would also like to thank Lila Daskalaki, Paulette Levy, B'alam Mateo, Devin Moore, Enrique Palancar, Jim Watters, Roberto Zavala, and an anonymous reviewer for Linguistic Discovery for helpful comments and feedback. Any errors that persist despite all this assistance are my own. This work was funded by the Social Sciences and Humanities Research Council of Canada.

2 The abbreviations used in the interlinear glosses are as follows: 1, 2, 3 first-, second, third-person; ADD additive; AGT agentive; ALD already; ALTV allative; AMB ambulative; AOR aorist; APPL applicative; ART article; ASP aspect; BEN benefactive; BLV belief; CAUS causative; CL clitic; CLF classifier; CMT comitative; DAT dative; DCS decausative; DET determiner; DIST distal; DSD desiderative; DTV determinative; EVID evidential; FOC focus; FUT future; GNC generic; HREL human relativizer; IDF indefinite voice; IDPH ideophone; IMPF imperfective; INDEF indefinite; INCH inchoative; INST instrumental; IRR irrealis; JNCT juncture; LOC locative; LOCREL locative relativizer; MID middle; MOM momentaneous; NEG negative; NMLZR nominalizer; NREL non-human relativizer; OBJ object; OPT optative; PRO pronoun; PATH in passing; PF perfect; PFV perfective; PL plural; PLC place; PO primary object; POSS possessive; PROG progressive; PTCL particle; QTV quotative; RCP reciprocal; REFL reflexive; REL relativizer; RPT repetitive; SAPSV suppressive antipassive; SG singular; SO secondary object; ST stative; STM stimulus; SUB subject; SUPP suppressive; TRNS transitivizer; TOT totalitative; VIA means. Abbreviations for the same term have been standardized across all sources. Examples written in practical orthographies in the original sources are given in an Americanist Phonetic Alphabet in order to facilitate comparison. The acute accent in transcriptions represents word-level stress. Unattributed data from Upper Necaxa Totonac are taken from my own fieldnotes and textual corpus.
} 


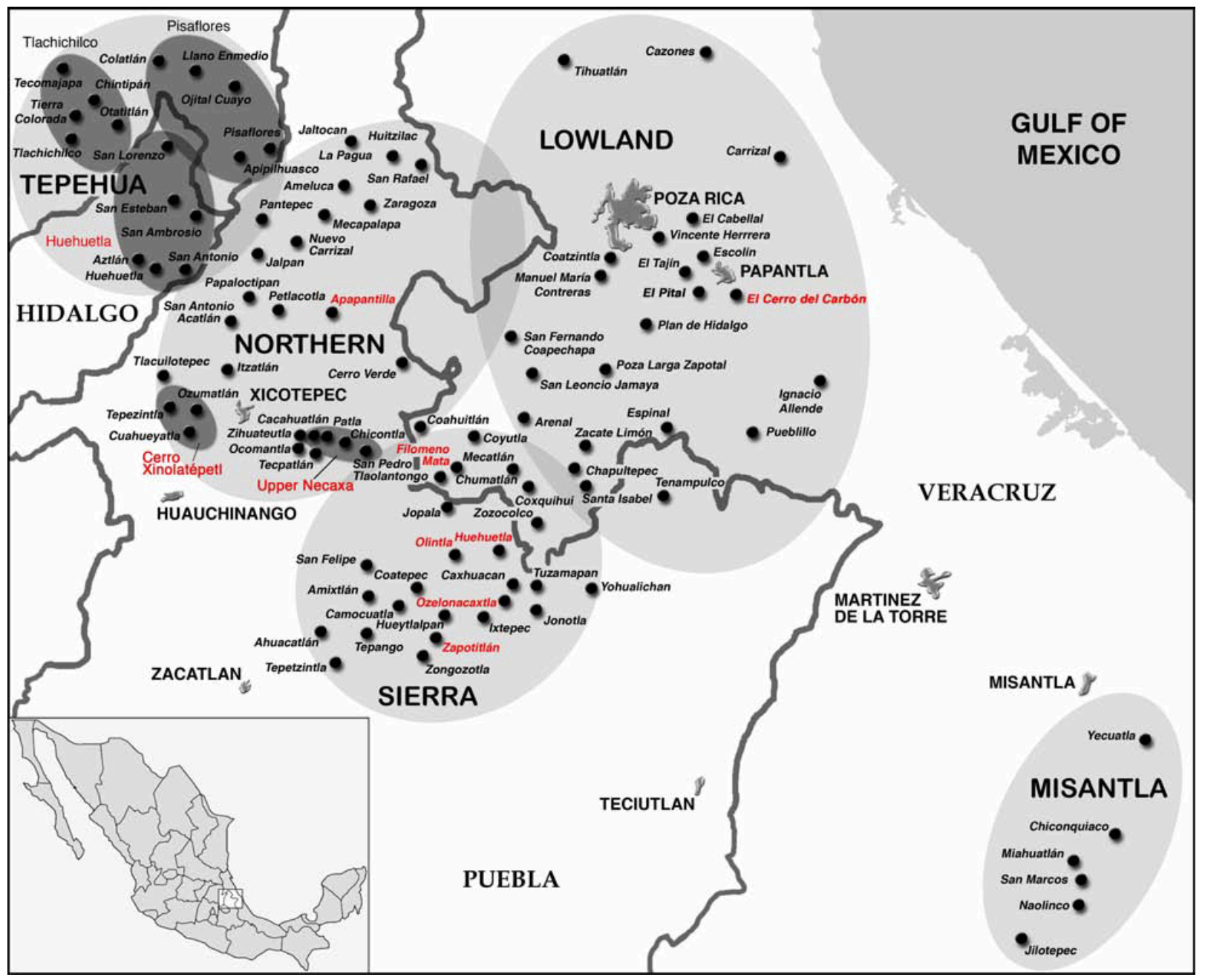

Figure 1: Location of Totonacan Languages

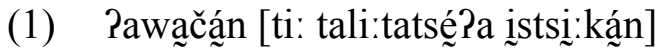


'those boys that hide behind their mother('s skirts)'

Here we see a typical relative construction with an overt nominal, Pawačán 'boys', being modified by a subordinate clause. The modified noun, or head of the relative clause, is external to the relative clause itself and is linked to it by a relativizer - in this case, the animate (human) relativizer, ti: The head of the relative clause corresponds to the subject of the embedded verb, which is elided or gapped, and the relative construction as a whole can be considered subjectcentred (i.e., the head of the clause is co-referential with the subject of the subordinated verb). Upper Necaxa also allows headless relative clauses (a.k.a. free relatives), as in (2): 
Upper Necaxa Totonac

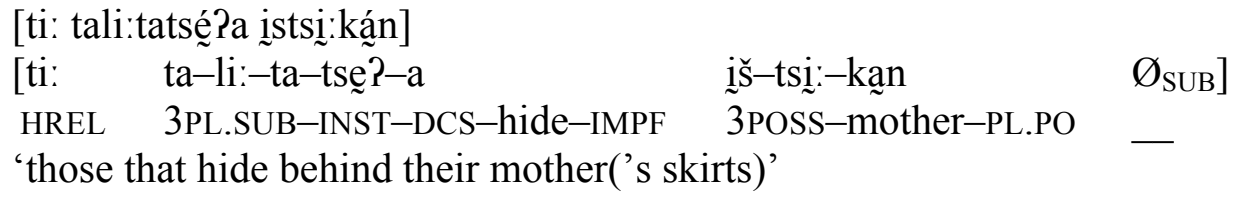

In a construction like this, the head of the relative clause is elided. The subject in (2) is also gapped, but the relative remains subject-centred and the referent of the construction as a whole is the subject of the embedded clause. Such constructions in Upper Necaxa function quite happily as arguments of verbs, like any other noun phrase, and are frequent in text.

In addition to the constructions in (1) and (2), Upper Necaxa also allows a third possibility, shown in (3):

\section{Upper Necaxa Totonac}

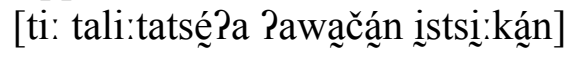

[ti: ta-li:-ta-tsęr-a Pawačáa $-\mathrm{n}$ iš-tsi:-kan]

HREL 3PL.SUB-INST-DCS-hide-IMPF boy-PL 3POSS-mother-PL.PO

'those boys that hide behind their mother('s skirts)'

In (3), there is no overt nominal head external to the subordinate clause. Instead, what appears to be the head, Pawačán 'boys', is found inside the embedded clause, in this case immediately following the verb. This type of construction is what is referred to as an internally-headed relative clause. Cross-linguistically, internally-headed relative clauses are comparatively rare, and they are even rarer in languages where, as in Upper Necaxa, they are an infrequent, as opposed to a dominant, type of relative clause (Dryer 2013).

Another notable feature of the constructions in (1)-(3) is the element $t i$, which is used exclusively in relative clauses with animate (human) heads and which has a counterpart, $t u$ :, used with inanimates (non-humans). While these are typically labeled "relativizers" in grammatical descriptions of Totonacan languages, this term is actually (and probably deliberately) vague in that it does not make it clear whether the relativizers are to be understood as subordinators or complementizers - linking elements in the clause signalling/licensing subordination - or as relative pronouns, pronominal elements standing in for the relativized argument of the embedded verb. The fact that they encode animacy, a characteristic of nouns, suggests that they might in fact be pronouns, as does the fact that in several of the languages in the family, like Upper Necaxa, they are homophonous with the interrogative pronouns, $t i$ : 'who?' and $t u$ : 'what?'. On the other hand, the relativizers are not, as canonical relative pronouns are, inflected for case, nor is animacy a morphological or inflectional category that manifests itself in other kinds of pronouns or in any other area of the grammar. So, not only does Upper Necaxa have the crosslinguistically unusual internally-headed type of relative clause, there is also an analytical question at play here as to the exact nature of the relativizers that appear in the relative constructions. As this paper will argue, these two phenomena are linked, and the presence of the internally-headed construction in (3) can be used to show that the relativizers are best not analyzed as relative pronouns in the usual sense, but should instead be described as complementizers that, perhaps unusually, agree with a semantic feature of the head of the relative constructions that they introduce. This agreement, naturally, has a diachronic explanation which is revealed by a comparative examination of relativization strategies across the family. 
The remainder of this paper will proceed as follows. Section 1 offers a brief description of Upper Necaxa Totonac, focusing on the structure of the simple clause, while Section 2 gives a detailed account of relativization in that language. In Section 3, I survey what is known about relativization in the rest of the family. The data available is rather sketchy as there are only one or two dedicated descriptions of relative clauses in other Totonacan languages; nevertheless, a reasonably coherent picture of the family, and how the different branches of Totonacan compare to each other and to Upper Necaxa, can be arrived at by culling through texts and other sources. Section 4 will assess the implications of the comparative picture for the diachronic development of the different relativization strategies, and will propose an analysis of the relativizers that supports the claim that they are best described as complementizers, at least in Upper Necaxa and the other languages in the family that allow internally-headed relative clauses.

\section{Upper Necaxa Totonac}

Upper Necaxa Totonac is a member of the Northern Totonac branch of the Totonacan language family, spoken by 3,293 people (INEGI 2010) in the Necaxa River Valley in northern Puebla State, Mexico. Like all Totonacan languages, Upper Necaxa can be characterized as polysynthetic and primarily head-marking in the sense of Nichols (1986). Verbs agree in person and number with their syntactic subjects; transitive verbs also agree with their objects:

(4) îna:pa:1'á:ł páśñi

ik-ka:-pa:-1'a:-li pášni

1SG.SUB-PL.OBJ-belly-cut.deeply-PFV pig

'I gutted the pigs.'

In (4) we see the verb pa:t'a: 'X cuts Y's belly deeply' bearing the first-person singular subject

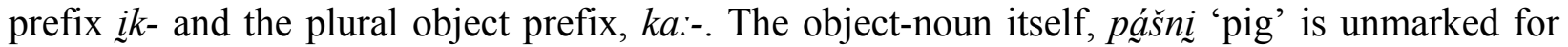
number, which is an optional category for nouns, the preferred locus for number-marking in the clause being on the verb. The categories of person and number of object are marked separately, as in (5):

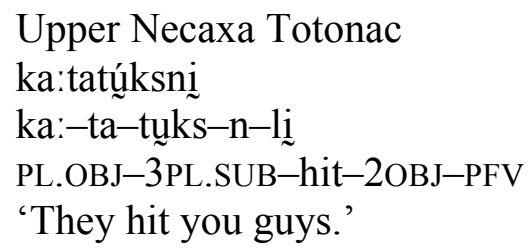

Here, the person of the object is encoded by the suffix, $-n$ 'second-person object', while the plural number of the object is indicated by the same prefix, $k a$ :- 'plural object', that we saw in (4). Third-person singular subjects, third-person objects, and the singular of objects are morphological zeros (and in this paper will not be included in the glossing to avoid cluttering the presentation).

In multivalent clauses, verbs can also agree in person with a second object, if that object is first- or second-person: 
(6) wan tsưmaxá:t, kinta:tá kista

wan tsựaxá:t kin-ta:tá $\quad$ kin-sta:-maškí:-n

say girl 1POSS-father 10BJ-sell-give-2OBJ

"The girl says, "My father sold me to you.",

This example shows the trivalent verb sta:maški' ' $\mathrm{X}$ sells $\mathrm{Y}$ to Z', used in this context to refer to the exchange of a girl for a dowry, agreeing with both a second-person and a first-person object. Upper Necaxa is a primary-object language in the sense of Dryer (1986), making the secondperson recipient in this clause the primary object and the first-person theme the secondary object. $^{3}$

Copular clauses can have either nominal (7) or adjectival (8) predicate complements:

Upper Necaxa Totonac

(7) šantíl šwaní: išna:ná Xiwán

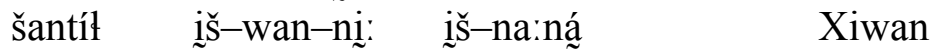

shaman PAST-be-PF 3POSS-grandmother Juan

'Juan's grandmother was a shaman.'

(8) kiłstayankatưnka tsamá mačí:ta

kil-stayánka =tưnká tsămá mačíta

mouth-sharp=very that machete

'That machete is very sharp.'

The copula is based on the verb wan 'be' and is immediately preceded by its complement, as it is in other Totonacan languages. In the past tense, the copula is invariably inflected in the past perfect, and in the future it takes the future imperfective form nawán. It is generally omitted in the present tense, as here in (8), but may optionally be realized in the present imperfective form, wan. Also of note in (8) is the head-marked possessive construction išna:ná Xiwán 'Juan's grandmother' in which the possessed NP is inflected for the person of the possessor. The plurality of the possessor is optionally indicated by the suffix -kan (e.g., išna:nakán Xiwán Pe: Tséntũ 'Juan and Rosendo's grandmother').

As in the rest of the family, constituent order in Upper Necaxa clauses is extremely flexible and is governed primarily by information/communicative structure (Vallduví 1992; Mel'čuk 2001). The communicatively unmarked order is verb-initial, placing Upper Necaxa in Dryer's (1997) VS/VO category; however, essentially any order of verb and arguments is possible for a given sentence in the appropriate context, as shown in (9):

\footnotetext{
${ }^{3}$ The properties of primary and secondary objects, and the criteria for distinguishing them, are discussed in Beck (2016). Without going into too much detail, the primary object includes the basic object of underived transitive verbs, the causee in causative constructions, and the recipient in underived verbs of transfer, while the secondary object includes the applied object added by an applicative and the thematic object of underived ditransitive verbs.
} 
(9) iščikắn ka:maškí:ł gobierno lạ̃škamani:ní:n $\quad$ SO V S PO

$\begin{array}{llll}\text { ǐš-čik-kan } & \text { ka:-maškí:-1 } & \text { gobierno } & \text { lå̃-škamaní:n-ni:n } \\ \text { 3POSS-house-PL.PO } & \text { PL.OBJ-give-PFV } & \text { government } & \text { APL-pauper-PL } \\ \text { 'The government gave the poor people their houses.' } & \end{array}$
ka:maški:t gobierno ląškamani:ní:n išščikán
V S PO SO
gobierno ka:maški:t lårškamani:ní:n ǐščikán
S V PO SO
ląiškamani:ní:n ka:maškít iščcikán gobierno
PO V SO S
gobierno låš̌kamani:ní:n ka:maškít i̛ščikán
S PO V SO, etc.

Although utterances in which all arguments are realized as NPs are relatively uncommon, sentences with all possible orders can be found in the corpus and are accepted during elicitation.

Copular clauses show flexible ordering of subject and predicate phrase, but the copula, when present, is preceded immediately by its complement in all but a few examples:

Upper Necaxa Totonac

šantíl šwaní: tsămá puská:t

šantíl iّš-wan-ni: tsamá puská:t

shaman PAST-be-PF that woman

'That woman was a shaman.'

tsamá puská:t šantít šwanĩ:

*tsamá puská:t šwaní: šantít

*šantít tsamá puská:t šwaní:

?šwaní: šantít tsamá puská:t

The final order shown here occurs occasionally, most often in the context of elicitation-bytranslation of Spanish sentences, but it is usually rejected or corrected by speakers when offered. It seems likely to be an effect of calquing from Spanish (cf. era bruja esa mujer).

Like predicate complements, most types of adverbial are also required to precede the verb:

Upper Necaxa Totonac

li:škamani:ntunká išwí:ł naiščćk tsamá puská:t

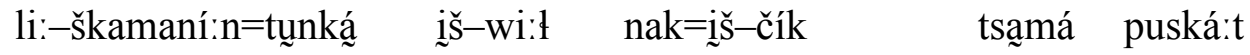

GNC-pauper $=$ very PAST - sit $\quad$ LOC $=3$ POSS-house that woman

'The woman lived in great poverty in her house.'

li:škamani:ntunká naǐščík iِšwi:t tsamá puská:t

li:škamani:ntunká ǐšwít tsamá puská:t naǐšč́k

li:škamani:ntũnká tsamá puská:t išwí: naiščík

*išwít li:škamani:ntunká naǐšč́k tsamá puská:t

Ideophones as well as dynamic, configurational, descriptive, and manner adverbs obligatorily precede their verbal heads, while temporal and locative adverbials like naǐščík 'in her house' in (11) may be either pre-verbal or post-verbal (Beck 2008). 
Constituent ordering is also relatively more fixed in information questions (a.k.a. whquestions), which require that the interrogative pronoun be the first element in the clause:

Upper Necaxa Totonac

ti: namín?

ti: $\quad$ na-min

who FUT-come

'Who is coming?'

(13) tu: li:mǻpni:?

tu: li:-márni:

what INST-kill:2SG.SUB:PFV

'What did you kill it with?'

Questions can be formed on any clausal constituent. In addition to $t i$ : 'who?' and $t u$ : 'what?', Upper Necaxa has the interrogatives $x a:$ : 'where?' and xá:kšni 'when?', the former but not the later also being homophonous with the corresponding relativizer.

\section{Relative clauses in Upper Necaxa Totonac}

Relative clauses in Upper Necaxa Totonac are first described in Beck (2004), where they are characterized as being externally-headed or headless, with a gapped argument inside the embedded clause. Relatives are introduced by what is characterized as a relativizer, either $t u$ : or $t i$, depending on the animacy of the head of the construction. Example (14) illustrates a relative clause with an inanimate nominal head:

Upper Necaxa Totonac

yúxa tsămá ška:n [tu: wanikán čá::wa] ]

yux-a tsămá ška:n [tu: wan-ni-kan $\varnothing_{\text {So }} \quad$ čá:wa $]$

go.down-IMPF that water NREL say-BEN-IDF _ sooty.water

'The water that they call "čá: $w a$ " comes down.'

The head of the relative clause is ška:n 'water' and corresponds to the gapped object of the intransitive verb wani ' $\mathrm{X}$ calls $\mathrm{Y} \mathrm{Z}$ '. The clause follows its head and is introduced by the nonhuman relativizer, $t u$ : The relativizer appears on the left edge of the clause and in most cases immediately follows the modified noun, although there are a few examples from texts in which the relative clause is separated from its head, as in (15):

Upper Necaxa Totonac

ištaąkłma:štuní išstumi:nkạ́n išpuska:tkấn [tu: tsạx šma:n natali:wá púkki]

iš-ta-äkłma:štú-ní iš-tumí:n-kan $\quad$ iš-puská:t-kan $\quad$ [tu: tsạx

PAST-3PL.SUB-set.aside-BEN 3POSS-money-PL.PO 3POSS-wife-PL.PO NREL only

šma:n na-ta-li:-wa púki $\left.\quad \varnothing_{\text {so }}\right]$

only FUT-3PL.SUB-INST-eat pulque

'They hid some of their money from their wives which they would use to drink pulque.' 
The relative clause in (15), tu: tsax šma:n natali:wá pútki 'which they would use to drink pulque', modifies the noun išstumi:nkán 'their money', the secondary object of the embedded verb, but is separated from it by the NP ǐspuska:tkán 'their wives'.

Example (16) shows a relative clause introduced by the human relativizer, $t i:$ :

\section{Upper Necaxa Totonac}

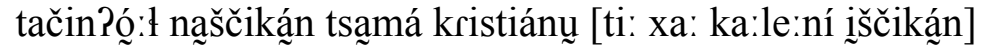

$\begin{array}{llll}\text { ta-čin-PQ:-1 } & \text { nak=iš-čik-kan } & \text { tsamá } & \text { kristiánu } \\ \text { 3PL.SUB-arrive-TOT-PFV } & \text { LOC=3POSS-house-PL.PO } & \text { that } & \text { person }\end{array}$

$$
\begin{aligned}
& \text { [ti: xa: ka:-le:n-ni } \quad \varnothing_{\text {so }} \quad \text { iš-čik-kan] } \\
& \text { HREL NEG PL.OBJ-take.away-BEN _ 3POSS-house-PL.PO }
\end{aligned}
$$

'They all came to the houses of the people from whom (the flood) hadn't taken their homes.'

In this example, the head of the relative clause, kristiánu 'person', corresponds to an object of the embedded verb le:ni ' $\mathrm{X}$ takes $\mathrm{Y}$ away from $\mathrm{Z}$ '. The form of the relativizer indicates that the head of the clause is human, but gives no indication of its number.

Relatives can also be formed from copular clauses, as in (17):

\section{Upper Necaxa Totonac}

ikląapása puská:t [ti: šantíl šwaní:]

ik-ląapás-a puská:t [ti: šantíl ịš-wan-ni: $\left.\varnothing_{\mathrm{SUB}}\right]$

1SG.SUB-know-IMPF woman HREL shaman PAST-be-PF -

'I know the woman who was a shaman.'

As in the previous examples, the relative clause immediately follows the noun it modifies and is introduced by a relativizer, in this case $t i$, which encodes the animacy of the head.

Headless relative clauses are illustrated in (18) and (19):

\section{Upper Necaxa Totonac}

wi:t [ti: kili:ą̧špa:wakál]

wi:ł [ti: kin-li:-ã̂špa:-wakáa $\left.\quad \varnothing_{\mathrm{SUB}}\right]$

sit HREL 1OBJ-INST-back.of.head-be.high

'There is someone resting their head on me.'

(19) a: wi:1 [tu: putsapá́:]

a: wi:t [tu: putsá-pa: $\left.\varnothing_{\mathrm{PO}}\right]$

there sit NREL look.for-PROG:2SG.SUB

'There is what you are looking for.'

In both of these sentences, the matrix verb is wi:t, which literally means 'be sitting' but is also used as a general existential locative ( $\approx$ Eng. 'be there'). The headless relatives in both examples take the role of matrix subject. The relative clause in (18) is a subject-centred clause, introduced by $t i$, with an animate referent, while that in (19) is an object-centred clause, introduced by $t u$;, with an inanimate referent. 
Headless relatives formed on copular clauses are also attested, both with and without an overt copula:

Upper Necaxa Totonac

ikląapapása [ti: šantí:ł šwaní: ]

ik-lårapás-a [ti:

1SG.SUB-recognize-IMPF HREL shaman PAST-be-PF _-

'I know the one who was a shaman.'

(21) ĩk Pawaxní tu: šamásni

ik-Pawaxní [tu: ša-mas-ni $\left.\quad \varnothing_{\text {SUB }}\right]$

1SG.SUB-disgusted NREL DTV-rot-NMLZR

'I am disgusted by things that are rotten.'

Such clauses are necessarily subject-centred, as relative-clauses centred on a predicatecomplement seem impossible, or at least difficult to conceive of. ${ }^{4}$

Research subsequent to 2004 has shown that, in addition to externally-headed and headless relatives, Upper Necaxa also has internally-headed relative clauses like those in (22):

Upper Necaxa Totonac

lú:wa [ti: tas'Q Panán tsumaxáá:n]

tú:wa [ti: ta-s'Q?á-nan tsựaxá:t-n]

many HREL 3PL.SUB-hug-SAPSV girl-PL

'There are a lot of girls who hug.'

In (22), the head of the relative clause, tsumaxá:n 'girls', corresponds to the plural subject of the antipassivized verb, $s$ 'o?anán 'X gives hugs', and occurs inside what is otherwise identical to a headless relative construction such as that in (18). That these constructions are indeed internallyheaded, rather than right-headed, can be seen in (23):

Upper Necaxa Totonac

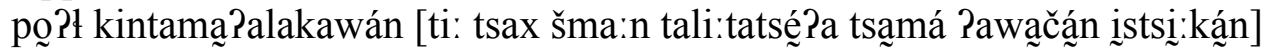

po?1 kin-ta-mąa-laka-wan [ti: tsax šma:n

fed.up 1OBJ-3PL.SUB-STM-face-say HREL just only

ta-li:-ta-tse?-a tsamá Pawačăa - n iš-tsi:-kan]

3PL.SUB-INST-DCS-hide-IMPF that boy-PL 3POSS-mother-PL.PO

'Those boys that hide behind their mother('s skirts) really bother me.'

Here the head of the construction is Pawačán 'boys'. It functions as the subject of the embedded

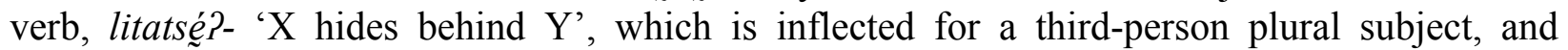
appears followed by the verb's object, istsị.kán 'their mother(s)'. Such constructions, while not abundant, occur naturally in spontaneous speech and are accepted readily in elicitation. Thus, it

\footnotetext{
${ }^{4}$ It is, of course, possible to conceive of (and form) relative clauses of the 'which' and 'what kind of' types (e.g., "I know which/what kind of doctor John is"); however, these are slightly different constructions in Upper Necaxa.
} 
seems that Upper Necaxa allows for three types of relative clause-externally-headed, headless, and internally-headed.

Other than the presence of the relativizer, Upper Necaxa relative clauses seem virtually identical to matrix clauses and show the same flexibility with respect to the ordering of arguments - although there is a dispreference for arguments of the embedded clause in pre-verbal position. Such constructions are difficult to elicit, but examples such as (24) are found in texts:

Upper Necaxa Totonac

[ti: šte:kưtunkă ška:n šwanikán]

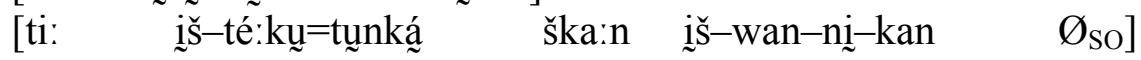

HREL 3POSS-owner=very water PAST-Say-BEN-IDF _

'the one that they call the spirit of the water himself'

In this example, the primary object, išté:ku ška:n 'the spirit of the water', precedes rather than follows the verb. Fronting of arguments in general seems to be associated with focalization (Mel'čuk 2001), and in the examples where an element inside a relative clause is fronted there is a clear emphatic or focal attention on that element. In (24), this is reflected by the presence of the intensifying clitic =tunká and the Spanish gloss given by the consultant, el mero dueno del agua 'the very/the one and only spirit of the water'.

Similarly, adverbials also maintain the pre-verbal position found in matrix clauses:

Upper Necaxa Totonac

čă:tín puská:t [ti: li:škamaní:n iָšwí:ł naiščćk]

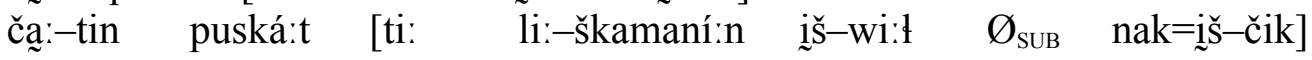

CLF-one woman HREL INST-pauper PAST-sit _ LOC $=3$ POSS-

'a woman who lived in poverty in her house'

house

ča:tín puská:t [ti: li:škamani:ntunká naišččk išší:t]

*ča:tín puská:t [ti: išswi:t li:škamani:ntunká naiščík]

As shown in (25), the manner adverb obligatorily precedes the verb, while the locative is permitted in either pre-verbal or post-verbal position. These rules of constituent order apply both when the clause is headless and when it is internally, rather than externally, headed.

In terms of accessibility to relativization, Upper Necaxa allows for the relativization of elements of virtually all applicable ranks on the Accessibility Hierarchy (Keenan and Comrie 1977). Examples of relatives centred on subjects, primary objects, secondary objects and possessors can be found in texts. ${ }^{5}$ The sentence in (26) shows a subject-centred relative clause:

\footnotetext{
${ }^{5}$ Upper Necaxa lacks prepositions (and, therefore, prepositional objects) and the category of "oblique object" as disinct from "secondary object" does not exist (Beck 2016), so these positions on the Accessiblity Hierarchy are not available for relativization.
} 
Upper Necaxa Totonac

\begin{tabular}{|c|c|c|c|c|c|}
\hline$\tilde{\mathrm{i} k}$-ławá-palá & 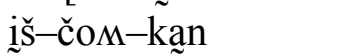 & lakstín & {$[\mathrm{ti}:$} & ta-an & $\varnothing_{\mathrm{SUB}}$ \\
\hline $\begin{array}{c}\text { 1SG.SUB-make-RPT } \\
\text { nak }=\text { skwela }] \\
\text { LOC }=\text { school }\end{array}$ & 3POSS-tortilla-PL.PO & children & HREL & 3PL.SUB-go & - \\
\hline
\end{tabular}

Here, the head of the relative clause lakstin 'children' is coreferential with the subject of the embedded verb, taán 'they go'. A headless subject-centred relative clause is shown in (27):

Upper Necaxa Totonac

iktåra:šnimá:ł wačí wi:1 [tu: nakilaní]

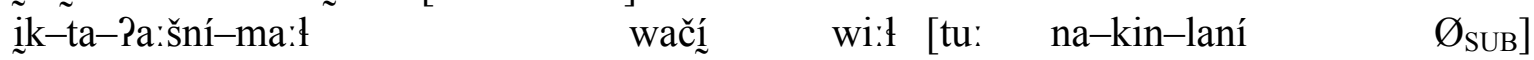
1SG.SUB-DCS-feel.forboding-PROG apparently sit NREL FUT-1OBJ-happen.to _ 'I feel like there is something that is going to happen to me.'

The headless relative here is based on the verb lani ' $\mathrm{X}$ happens affecting $\mathrm{Y}$ ', which is formed by adding the benefactive applicative $-n i$ ' to the light verb la ' $\mathrm{X}$ happens'. The gapped argument corresponds to the subject of the verb, the event that happens and affects Y.

Internally-headed subject-centred relative clauses are also attested as in (28):

Upper Necaxa Totonac

(28) kalǻptsi, [ti: natawilá is’ ǻta], nakšãa: nama:ša a ani:kán

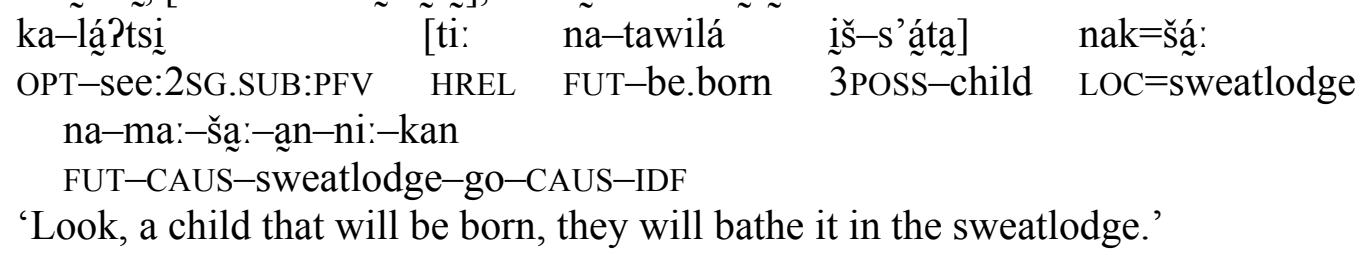

Relatives formed on copular clauses can also be internally-headed:

Upper Necaxa Totonac

ikla حapapása [ti: šantí:ł šwaní: puská:t]

ik-ląapás-a [ti: šantí:1 iš-wan-ni: puská:t]

1SG.SUB-recognize-IMPF HREL shaman PAST-be-PF woman

'I know a woman who was a shaman.'

Not unexpectedly, then, it appears that all subjects are accessible to relativization.

In terms of object relations, both primary and secondary objects are accessible. In (30), we

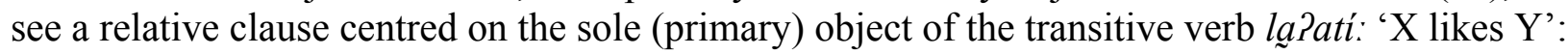


Upper Necaxa Totonac

wiš kalaksákti [ti: tsex ląatí:ya]

wiš ka-laksák-ti [ [ti: tsex la

you OPT-choose-2SG.SUB:PFV HREL well like-IMPF:2SG.SUB

'Pick the one (girl) that you like best!'

(31) also shows a headless primary-object centred relative clause:

Upper Necaxa Totonac

tiyạa? laklahtsáá, xa:tsắ la [tu: čankán]

tiyắ? laklá-1=tsá $\quad$ xa:=tsá la [tu: čãn-kan $\left.\emptyset_{\mathrm{PO}}\right]$

land ruined-PFV $=$ now $\mathrm{NEG}=$ now do NREL plant-IDF -

'The earth is ruined, what you plant doesn't grow.'

The reference of the relative clause in (31) is to the object of the verb čan ' $\mathrm{X}$ plants $\mathrm{Y}$ '. In this example, the verb čan is inflected for the indefinite voice, which suppresses the expression of the subject but does not promote a first- or third-person object to subject position (Beck 2004, 2016). Verbs in this voice have either an indefinite subject $(\approx$ Eng. indefinite they or you $)$ or a reflexive reading.

An internally-headed primary-object centred relative clause is shown in (32):

Upper Necaxa Totonac

xa: kło:kưún [tu: kło:má:ł kintaskuxút]

xa: ijk-lawá-kutún [tu: ik-lawá-ma:1 kin-taskuxút]

NEG 1sG.SUB-make-DSD NREL 1SG.SUB-make-PROG 1POSS-job

'I don't want to do my job that I'm doing.'

The head of the relative clause is the primary object of tawa 'X does Y', kintaskuxút 'my job', and it appears in this sentence inside the embedded clause.

An externally-headed secondary-object centred relative clause is shown in (33):

Upper Necaxa Totonac

ya:wa:nikán å̃tín [tu: li:lakattajte:kán]

ya:wá:-ni-kan å̃-tin [tu: li:-laka-tan-tayá-kan $\left.\quad \emptyset_{\text {so }}\right]$

stand-BEN-IDF CLF-one NREL INST-face-pull.taut-take-IDF

'They stood up against it something that they could use to pull it tight.'

In (33), the head of the relative clause is the applied, secondary object of the verb li:lakattaytayá 'X pulls Y taut with Z', formed from the verb lakattaytayá 'X pulls Y taut' with the instrumental applicative prefix li:-. Note that in this example the head of the relative clause is a numeral classifier construction used anaphorically to mean 'something', although unlike the English something in the gloss, the expression is not necessarily indefinite (that is, in the right context the relative might have been translated as 'the thing that they could use to pull it tight').

A headless secondary-object centred relative clause is shown in (34): 


\section{Upper Necaxa Totonac}

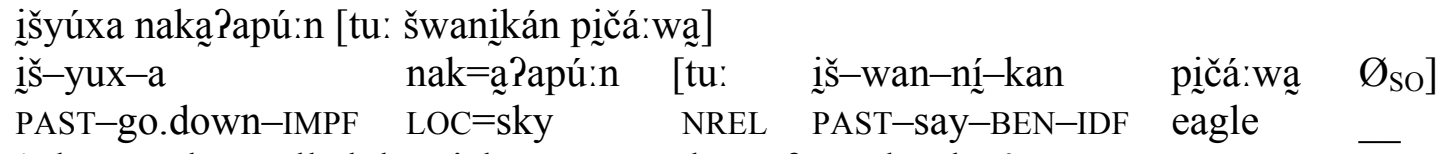

'The one they called the Pichawa came down from the sky.'

The referent of the clause here is the animal being named, which corresponds to the applied object of the verb wani ' $\mathrm{X}$ says $\mathrm{Y}$ to $\mathrm{Z}$ ', the translation equivalent of English call/name, which is formed from the verb wan ' $\mathrm{X}$ says $\mathrm{Y}$ ' by adding the benefactive applicative suffix $-n i$. The same verb can be seen in an internally-headed secondary-object centred relative clause in (35):

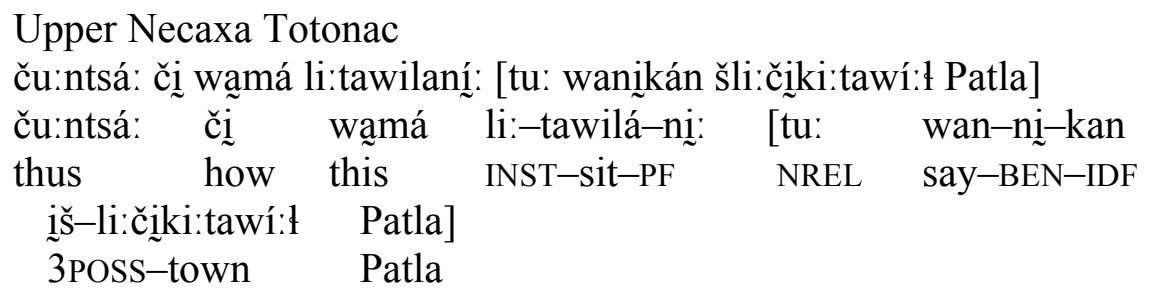

'That is the way their town that they named Patla was founded.'

In (35) the head of the relative is the object being named, išli:čiki:tawi:t 'their town', which is realized inside the embedded clause, to the left of the primary object, the name Patla.

The only type of construction that is clearly a relative clause centred on an adjunct is the locative-centred relative. Locative-centred relatives are introduced by $x a$ : 'where', as in (36):

Upper Necaxa Totonac

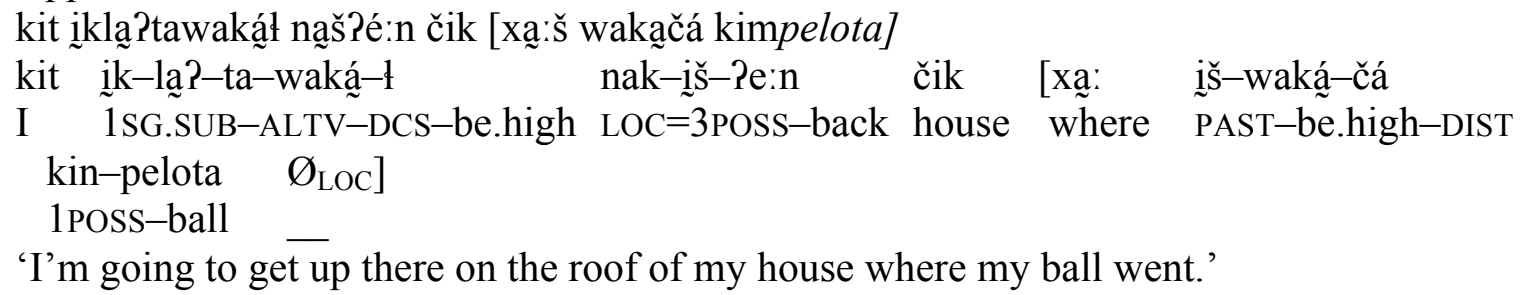

Perhaps unsurprisingly, locative-centred relatives are more frequently headless, as in (37):

Upper Necaxa Totonac

nakán ma:lå Papasní: xã nała: wán

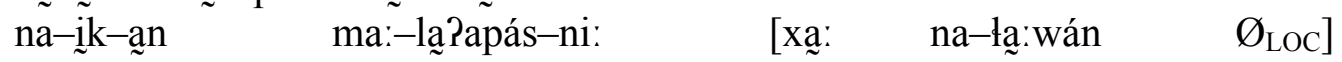

FUT-1SG.SUB-go CAUS-recognize-CAUS where FUT-walk _-

'I'm going to go show him where he's going to walk.'

While locative relatives seem to share some of the properties of relative clauses introduced by $t i$ : and $t u$; little more will be said about them in the remainder of this paper. Likewise, there are temporal constructions introduced by akšni 'when' that look very similar to relative clauses, but are not clearly attested modifying nouns. These will also be left aside in this discussion. ${ }^{6}$

\footnotetext{
${ }^{6}$ This also applies to the discussion of relative clauses in other Totonacan languages below, where I have excluded from consideration any type of adjunct-centred construction that is not attested as an adnominal modifier.
} 
Moving further down the Accessibility Hierarchy, a look through the corpus finds possessorcentred relative clauses, like those in (38) and (39):

Upper Necaxa Totonac

ka:šławáka čik [tu: lå̃apásła išventana]

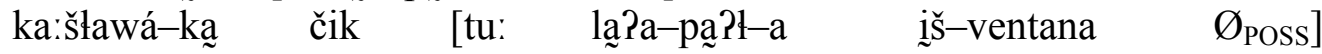

repair-IDF:PFV house NREL face-break-IMPF 3POSS=window

'They repaired the house whose windows s/he broke.'

(39) ka:mårta:yáka må̃a:pitsín kristiánu [ti: iָštanu:ní: pu:łú:n naiščík]

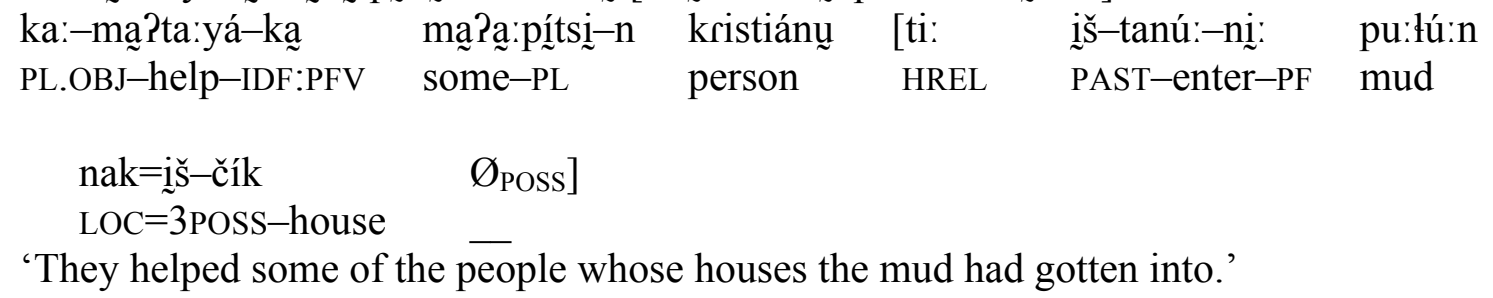

Headless and internally-headed versions of relatives of either the possessor- or comparativecentred types have not been found or elicited, though it seems entirely possible this is simply a gap in the data rather than a specific grammatical restriction. I have not been able to elicit relative clauses centered on the standard of comparison, although I have elicited relatives centered on the subject of the comparative construction, like that in (40):

\section{Upper Necaxa Totonac}

ikputsá ča:tín tsữaxá:t [ti: a:čulá: tse:waní či wišs]

ik-putsá čã -tin tsumaxá:t [ti: a:čulá: tse:waní $\emptyset_{\text {SUB }}$ či wiš]

1SG.SUB-look.for CLF-one girl HREL more pretty _ like you

'I'm looking for a girl who is prettier than you.'

\section{Relative clauses in Totonacan}

As we've seen in the preceding section, Upper Necaxa takes a rather free-wheeling approach to relativization, allowing externally-headed, headless, and internally-headed constructions, and permitting relativization along nearly the full length of the Accessibility Hierarchy. Constituent order in relative clauses continues to be flexible, though there seem to be discourse conditions on "fronting" NPs to a position between the verb and the relativizer. The relativizers themselves make a human/non-human animacy distinction and, in this respect (showing some sort of agreement with the head of the relative construction), resemble pronouns. Taken together, this is an unusual typological profile, particularly with respect to the presence of internally-headed relative clauses. According to Dryer (2013), internally-headed relative clauses are rare, found in only 63 languages in his 824-language sample (7.6\%) and occurring as a non-dominant (less frequent) type in only $10(1 \%)$. The fact that internally-headed relatives in Upper Necaxa are not in any sense nominalized contradicts a universalist claim made in de Vries (2005: 18) that such structures are always nominalized, and are only found in languages that have a similar type nominalized non-relative clauses (which Upper Necaxa lacks). Likewise, de Vries (2005: 19) claims that internally-headed relatives should only be found in languages with RelN and NDet 
order, neither of which is true of Upper Necaxa, although a loose correlation of RelN order with the presence of internally-headed relatives clauses appears to be borne out by the data in Dryer (2013). In the (surprising) absence of large-scale, quantitative typological studies of the Accessibility Hierarchy, it is not possible to determine how unusual access to such a wide range of elements on the Hierarchy is, though presumably it is relatively infrequent given the number of other possible language types foreseen by the Hierarchy. Given the interesting profile of Upper Necaxa relative clauses, it seems worthwhile at this point to turn to other languages in the family, with an eye towards seeing what, if any, of these features are shared by other languages in the group, and if the familial pattern sheds any light on the nature of the Upper Necaxa relativizers.

\subsection{The Totonacan language family}

The internal structure of the Totonacan family is still not well understood, though, as shown in Figure 2, it is generally agreed that Totonacan languages can be divided at the highest level into two branches, Tepehua and Totonac. Tepehua is considered to consist of three languagesTlachichilco, Pisaflores, and Huehuetla, while Totonac is more highly ramified and contains an as-yet-unknown number of languages. The most basal division in the Totonac branch of the family is between the geographical outlier Misantla Totonac and the remaining Central Totonac languages. Central Totonac has traditionally been held to consist of three sub-groupingsNorthern, Sierra (a.k.a. Highland), and Lowland (Papantla). Beyond this, the relations become murkier, and there have been various proposals for grouping together Northern and Sierra against Lowland (García Rojas 1978), Lowland and Northern against Sierra (MacKay and Trechsel 2014, 2015), and Northern against Lowland-Sierra (Ichon 1969; Davletshin 2008; Brown et al. 2011). Presently, the weight of the evidence, particularly the lexical evidence, seems to favour the last of these. There are, in addition, further uncertainties, and particularly problematic are the affiliations of Cerro Xinolatépetl and Filomeno Mata. While Cerro Xinolatépetl is not spoken in an area contiguous with Lowland-Sierra languages (see Figure 1 above), lexical evidence suggests its affinity is with these rather than with the adjacent Northern group. Filomeno Mata is grouped by MacKay and Trechsel (2014) in the Northern branch, based on shared morphological characteristics, and it does seem to be the case that this language also shares a few lexical forms with the Northern languages; however, the bulk of the lexical isoglosses, as well as statistical measures of lexical similarity, seem to point to a closer affiliation with Lowland-Sierra. 


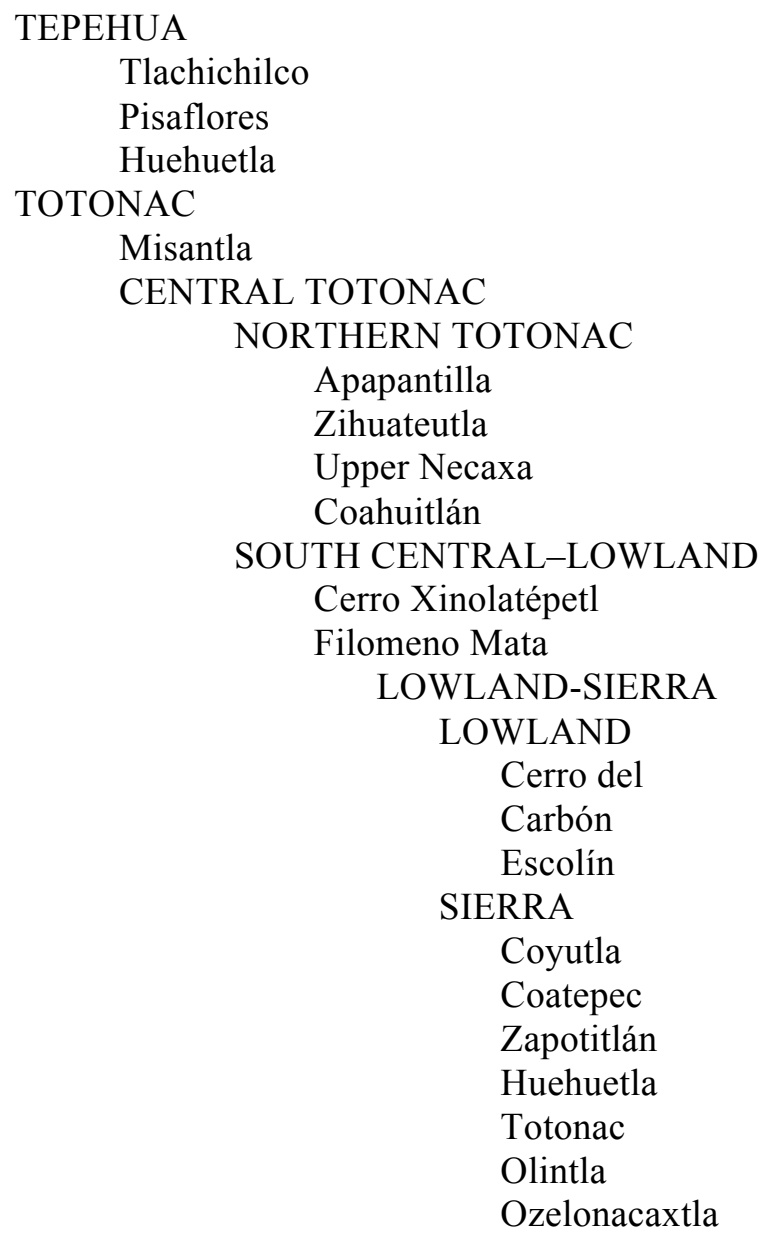

Figure 2. Totonacan languages

In terms of available descriptions of relativization strategies in Totonacan languages, the pickings are rather slim. For Tepehua, Smythe-Kung (2007) offers a sketch of relativization in Huehuetla, and some mention of relative clauses in Tlachichilco is made at various points in Watters (1988). In Northern Totonac, relative clauses are mentioned in passing in the pedagogical grammar of Apapantilla prepared by Reid (1991) and there are numerous unanalyzed examples in a lexical database for the language prepared by Reid et al. (n.d.). Relative clauses in Sierra languages are dealt with indirectly for Huehuetla Totonac in Troiani (2004) and for Coatepec in McQuown (1990). E. Aschmann (1984) presents a much more thorough and detailed description of all types of relatives in Zapotitlán Totonac, and additional examples from this language (again, unanalyzed) can be found in the lexical database prepared by $\mathrm{H}$. Aschmann (n.d.a). Likewise, a large number of unanalyzed sentences that contain relative clauses can be found in the examples in H. Aschmann's (n.d.b) lexical database for the Sierra Totonac language Coyutla. Unanalyzed translations of Spanish sentences containing relative clauses can be found for Misantla Totonac in MacKay and Trechsel (2005), and one or two examples of relatives can be found in analyzed texts in MacKay (1999) and MacKay and Trechsel (2012b). Beyond this, information on a few other languages can be gleaned from the interlinearized texts in Levy and Beck (2012) which contain examples of relative clauses from the Totonac languages Cerro Xinolatépetl, Filomeno Mata, Olintla, Ozelonacaxtla, and Cerro del Carbón, and for all three 
Tepehua languages. In the sections that follow, I will summarize what can be extracted from this fragmentary data, beginning with Tepehua in section 3.2 and then moving on to the Totonac group in section 3.3.

\subsection{Tepehua}

The most detailed description of relative clauses in Tepehua languages is found in SmytheKung's (2007) doctoral dissertation on Huehuetla Tepehua. Smythe-Kung gives examples of both externally-headed post-nominal (41) and headless (42) relative constructions:

Huehuetla Tepehua

šta?amaqpanan hu: papa:nin [hu: ka: wa: lakak'iwin štat'ahun]

š-ta-Pamaqpanan hu: papa?-nin [hu: ka: wa: laka-k'iwin

PAST-3PL.SUB-wash.clothes ART man-PL REL BLV FOC PREP-woods

$\check{\text { s}}-\mathrm{ta}-\mathrm{t}$ 'ahun $\left.\quad \emptyset_{\mathrm{SUB}}\right]$

PAST-3PL.SUB-live

'The men that were living in the woods would wash their clothes.'

(Smythe-Kung 2007: 590)

[hu: špula:ta tam p'aqlati tu:mi:n]

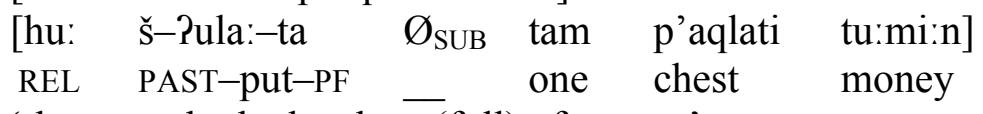

'the one who had a chest (full) of money'

(Smythe-Kung 2007: 597)

In both cases, these are subject-centred relative clauses introduced by a relativizer, $h u$; , which is homophonous with the article that is found introducing noun phrases such as the head of the relative clause in (41), hu: papa:nin 'the men'. The relativizer, like the article, is invariant and shows no agreement for number or animacy. Although Smythe-Kung makes no explicit reference to constituent order within the clause, none of her examples have fronted arguments and nothing precedes verbs except adverbial elements such as particles and the locative phrase seen in (41).

The issue of noun-phrase accessibility in Huehuetla is complicated by the fact that the terminology used in the description of this language does not map directly onto the categories traditionally used in the discussion of the Acessiblity Hierarchy. According to Smythe Kung (2007: 592), externally-headed relative clauses can be formed on subjects, direct objects, indirect objects, oblique objects, and locative adjuncts. For Smythe Kung, direct objects are the single objects of transitive verbs, and indirect objects are the recipients in ditransitive verbs such as that in (43): 
Huehuetla Tepehua

pu:s ka: yu: ̌̌ [hu: Pištaqnitač]

$\begin{array}{llllll}\text { pu:s } & \mathrm{ka}: & \text { yu: } \check{\mathrm{c}} & {[\mathrm{hu}:} & \text { Piš-štaq-ni-ta }=\check{c} & \emptyset_{\text {INDIRECT.OBJ }}\end{array}$

well BLV 3SG.PRO REL PAST-give-DAT-PF=ALD

'Well, I think that it was he to whom she had given it.'

(Smythe Kung 2007: 596)

The embedded verb in (43) is štaqni ' $\mathrm{X}$ give $\mathrm{Y}$ to $\mathrm{Z}$ ' which contains a fossilized instance of the dative applicative, -ni. Other applicatives such as $t$ 'a:- 'comitative' add what Smythe Kung calls "oblique" objects, as in (44):

Huehuetla Tepehua

ti:sčawayč [hu: t'a:?ot'i]

ti:sčawayč [hu: t'a:-qot-t'i Ø

who REL CMT-drink-2SG.SUB:PFV

'With whom was it that you drank?'

(Smythe Kung 2007: 596)

However, objects like these are oblique only in the semantic sense that they are not part of the basic valency of the verb; syntactically, it is not clear that they are oblique objects in the usual meaning of the term and, based on descriptions of applied objects in Tlachichilco (Watters 1989), they would probably not be considered "oblique" by Keenan and Comrie (1977), although they would still rank below direct objects and above locative adjuncts.

As in Upper Necaxa, locative relatives in Huehuetla Totonac make use of a separate element meaning 'where' to introduce the subordinate clause:

Huehuetla Tepehua

wa: Palin tałpa [hunta: ktapa:sayaw]

wa: Palin talpa [hunta: ktapasayaw

FOC there.is hill where 1SUB-pass-IMPF-1PL.SUB:PFV _

'There is a hill where we pass ...'

(Smythe Kung 2007: 598)

In Huehuetla, however, hunta: 'where', is not homophonous with the interrogative word for questioning locations, tanč 'where?' (Smythe Kung 2007: 567), and in this it differs from Upper Necaxa Totonac.

There is less information available about headless relatives in Huehuetla. Although Smythe Kung (2007: 592) writes that these are confined to subject-centred constructions, there is some evidence that other types of headless relatives are possible, as shown by the following example from the text in Smythe Kung (2012): ${ }^{7}$

\footnotetext{
${ }^{7} \mathrm{I}$ am grateful to an anonymous reviewer for pointing me to this example. The translations of the glosses from Spanish in this and subsequent examples from the texts in Levy and Beck (2012) are mine.
} 
Huehuetla Tepehua

hu: Panu:č [hu: Pula:ta hu: purowi: hu: lapanak]

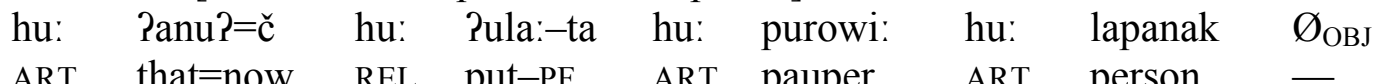

'what the pauper, the person had put there'

(Smythe Kung 2012: 71, line 26)

Here, the referent of the headless relative clause corresponds to the object of the verb Pula: ' $\mathrm{X}$ places Y'. It may be that the constraint against headless relatives formed on non-subjects noted by Smythe Kung is more of a dispreference than an absolute prohibition, and additional examples may surface in future investigations.

Relative clauses in Tlachichilco Tepehua have not been described in detail, although a few examples and some structural observations about them can be found in Watters (1988: 120, 4612, 467-72). According to Watters, both externally-headed (47) and headless (48) relative clauses can be formed from any "direct argument" of the verb: ${ }^{8}$

Tlachichilco Tepehua

ni ka:roh [yu: kpu:mil] yu:ča wa: Pałča

ni ka:roh [yu: k-pu:-min-1 $\left.\varnothing_{\text {OBJ }}\right]$ yu:ča wa: Pan-1=ča

ART car REL 1SUB-VIA-come-PFV - 3PRO FOC go-PFV=now

'The car I came in, it's gone already.'
[yu: kint'a:mil] wa: kilaqah
[yu: kin-t'a:-min-1 $\left.\quad \varnothing_{\text {ОвJ }}\right]$ wa: kin-laqah
REL 1OBJ-CMT-come-PFV _ FOC 1POSS-kinsman

'The one I came with is my relative(male).'

(Watters 1988: 120)

In both of these examples, the target of relativization is an applied object added to the valency of the verb by an applicative - pu:- 'means, path' in (47) and t'a:- 'comitative' in (48). Watters (1988) also presents examples of subject- (p. 472) and direct-object centred (p. 462) relative clauses, but does not mention the possibility of forming relative clauses on locative expressions.

As in Huehuetla, in Tlachichilco relative clauses are introduced by an element, $y u$;, that is homophonous with a determiner also used to introduce noun phrases-although, unlike Huehuetla, Tlachichilco has other determiners as well, and the one used with relative clauses is textually less-frequent (Watters 1988: 466). This also seems to be true of Pisaflores Tepehua, judging by the text in MacKay and Trechsel (2012a), where the cognate element, $y u u$, is glossed as 'that' or 'the one that' when introducing relative clauses, both externally-headed (49) and headless (50):

\footnotetext{
${ }^{8}$ I have adjusted the format of examples from this source to conform to the more up-to-date interlinearization practices followed in Watters (2012).
} 
Pisaflores Tepehua

máa?ǻča Pạ́n lapánaak [yúu máalaPą̌čáakał]

$\begin{array}{llllll}\text { maa-an- }-\mathrm{i}=\mathrm{c} a & \text { an } & \text { lapanaak } & \text { [yuu } & \text { maalaPačaa-kan-1i } & \emptyset_{\text {OBJ }} \\ \text { EVID-go-PFV=CL } & \text { DET } & \text { man } & \text { REL } & \text { send.X-INDEF.SUB-PFV } & -\end{array}$

'The man that they sent went.'

(MacKay and Trechsel 2012: 111, line 12)

(50) máatanahún [yúu tawilánančáał Påłma?åadạ́y]

maa-ta-nahun [yuu ta-wila-nan-čaał $\varnothing_{\text {SUB }}$ ałmarast'ay]

EVID-3PL.SUB-tell REL 3PL.SUB-sitting-PL-there _ up.there

'Say those who live in the North.'

(MacKay and Trechsel 2012: 111, line 9)

Both of these relatives, one subject-centred (50) and one objected-centred (49), are introduced by yuu (glossed here as a relativizer to facilitate comparison), which (50) shows to be invariant for number. Judging from some unanalyzed examples in MacKay and Trechsel (2010), Pisaflores may also have relative clauses introduced by the determiner ?an, though this remains to be confirmed by further investigation.

In summary, then, Tepehua languages use determiners or elements cognate with determiners to introduce both externally-headed and headless relative clauses which can be centred on any type of object; the presence of locative-centred relative clauses has only been substantiated for Huehuetla Tepehua. There is no evidence for internally-headed constructions in any of these languages, and all attested examples of relatives thus far follow predicate-initial constituent order in the embedded clause.

\subsection{Totonac}

The Totonac branch of the family is somewhat larger and more ramified than the Tepehua branch. In the sections below I will begin with the most divergent Totonac language, Misantla, and then move on to the Central group, divided up into Northern, Cerro Xinolatépetl, Filomeno Mata, Lowland, and Sierra subgroups.

\section{Misantla Totonac}

Relatively little is known about relative clauses in Misantla. While there is a very good grammar of Misantla Totonac (MacKay 1999), this work is focused primarily on the phonology and morphology of the language and does not touch at all on relativization. There are, however, some unanalyzed examples in MacKay and Trechsel (2005) that are given as translations of sentences that contain relative clauses in Spanish. These are all externally-headed constructions and most are introduced by an element glossed as a determiner in the texts in MacKay and Trechsel (2012b), as in the example shown in (51): ${ }^{9}$

\footnotetext{
${ }^{9}$ The interlinear glosses in (51) and (52) are mine, though I try to follow the glossing conventions used in MacKay and Trechsel (2012b) as much as possible. The translations from Spanish of the full glosses are mine as well.
} 
Misantla Totonac

táštuł hun čiškú? [hun ikmaqníinił iščičí?]

ta-štu-lał hun čiškú? [hun ik-maqníi-ni-1 $\quad$ iš-čičí? $\left.\quad \varnothing_{\text {OBJ }}\right]$

INCH-out-PFV DET man DET

'The man whose dog I killed came out.'

(MacKay and Trechsel 2005: 225)

The relative clause in (51) is centred on the applied object of the verb maqniini ' $\mathrm{X}$ kills $\mathrm{Y}$ affecting Z' licensed by the dative applicative -ni. It not clear exactly what rank on the Accessibility Hierarchy to assign this object, but MacKay and Trechsel (2008) argue that objects in Misantla are symmetrical in the sense of Bresnan and Moshi (1990). Thus, presumably, if one type of object can be relativized then they all can, and accessibility to relativization extends at least as far down the hierarchy as the lowest-ranked object. The determiner in this construction, hun, is an obvious cognate of the Huehuetla Tepehua article $h u:$.

There are also two examples of translations of Spanish sentences with externally-headed relative clauses where the corresponding elements in Misantla are not introduced by a determiner. If these are relative clauses, one — shown in (52) — would be subject-centred, and the other object-centred:

\section{Misantla Totonac}

iklá:min hun čišsú? [taqapíištán]

ik-la:-min-na hun čiškú? [taqapíi-štan $\left.\emptyset_{\text {SUB }}\right]$

1SUB-CMT-come-CMT DET man drunk-PAS

'I come with the man who was drunk.'

(MacKay and Trechsel 2005: 152)

There is also a sentence in the text in MacKay and Trechsel (2012b: 140-141, line 90) that could be a determiner-less subject-centred relative clause, though other interpretations of the structure are possible. Another possibility is that structures like that in (52) are in fact internally-headed relative clauses with a fronted argument (cf. the Zapotitlán example in 0 below), a hypothesis which merits further investigation.

It appears from a single example in the text at the end of MacKay (1999) that it may be possible to form headless relatives introduced by the determiner as well:

Misantla Totonac

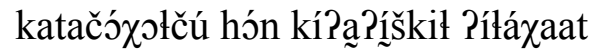

ka-ta-čuqu-la(1)-ču hun kin-a - $-\underset{\sim}{s} \mathrm{~s} k i-l a(1) \quad$ iš-laqaat

IRR-INCH-remain-PFV-CL DET 1OBJ-MOM-giveXtoY-PFV 3POSS-clothes

'He is left (behind), the one who lent me his clothes.'

(MacKay 1999: 447, line 41)

However, what appear to be headless relative clauses formed by a somewhat different strategy are also attested in the text in MacKay and Trechsel (2012b): 
Misantla Totonac

laká:čukús má:siyựštán tu:t lí:tapahánu:1

laka:=ču-kus ma:siyữ-štan tu:t lii-ta-pahanu:-la(1)

$\mathrm{NEG}=\mathrm{CL}-$ still tell.X-past what INST-INCH-happen-PFV

'He still did not tell what it was that happened.'

(MacKay and Trechsel 2012b: 156, line 164)

la: kakí:lǻ kawạ́n tú:pičú lí:łá:hat

$\begin{array}{lllll}\text { la: } & \text { ka-ki:-laqan-ti } & \text { ka-wan } & \text { tu:-pi?=ču } & \text { li:-la:ha-la(ł) } \\ \text { no } & \text { IRR-INTN-see.X-2sG:PFV } & \text { IRR-say.X } & \text { what-maybe=CL } & \text { INST-earn.X-pfv } \\ \text { 'No, go see him so that he might tell you what he earned (his riches) with.' }\end{array}$

(MacKay and Trechsel 2012b: 130-131, line 45)

If these are indeed relative clauses, we have a headless subject-centred relative clause in (54) and an (instrumental) object-centred construction in (55). Both are introduced by tu:(t) 'what', the cognate of the Upper Necaxa non-human relativizer. Thus, it seems possible that Misantla uses different relativizers for externally-headed constructions (and, potentially, internally-headed constructions if that is the correct interpretation of (52) above). However, given that both of these examples here involve a matrix verb of speaking (ma:siyu ' $\mathrm{X}$ recounts $\mathrm{Y}$ ' and wan ' $\mathrm{X}$ says $\left.Y^{\prime}\right)$, another possibility is that we are looking at sentential complements of verbs in the form of "embedded questions"-subordinate clauses introduced by interrogative words subcategorized for by a certain class of verb. These would not be relative clauses in the traditional sense in that they are not adnominal modifiers (a role filled in Misantla by the determiner-headed constructions seen in (51) above), but it seems like a very small step, both semantically and syntactically, between the use of constructions like these in the more restrictive context (complement of a specifc type of verb) to a less restricted use as an argument of verbs in general, making them the functional equivalent of headless relative clauses in sentences like the Upper Necaxa example in (18) above. Where exactly on this cline the Misantla $t u$ :-constructions are is still uncertain. Even so, it does seem to be the case that Misantla occupies an intermediate position between Tepehua, which makes exclusive use of a determiner in relativization, and Upper Necaxa (and other Totonac languages, as we'll see below), which has taken an additional step and extended the use of $t i: / t u$ : to adnominal relative constructions. We will return to this issue in section 4.

\section{Northern Totonac}

The only member of the Northern group of the Central Totonac branch of the family that has any substantial amount of documentation yet, other than Upper Necaxa, is Apapantilla. ${ }^{10}$ Not unsurprisingly, relative clauses in this language closely resemble those in Upper Necaxa, although the Apapantilla relativizers are gnti: and antu: The examples in (56) and (57) show externally-headed relative clauses with animate heads introduced by anti::

\footnotetext{
${ }^{10}$ A recent paper by Moore (2016), however, describes relative clauses for another Northern Totonac language, Coahuitlán; it appears that the facts in this language are largely the same as other members of the subgroup.
} 
Apapantilla Totonac

čiłtsá wan čiškú [anti: tama:wakưutun kuši]

čin-1=tsá wan čiškú $\quad$ [anti: tama:wa-kutun kuši $\left.\emptyset_{\text {SUB }}\right]$

arrive-PFV=now DET man HREL buy-DSD

'The man who wants to buy corn arrived.'

(Reid 1991: 58)

čittsá wan čiščú [anti: šaiqqąi:ma: ]

(57)
čin-1=tsá
wan
čiškú
[anti:
ša $\underset{\sim}{\mathrm{i}}-\underset{\sim}{\mathrm{k}}-\mathrm{qa}$ ati:-ma:
HREL
PAST-1SG.SUB-wait-PROG
'The man who I am waiting for arrived.'

(Reid 1991: 58)

The example in (56) is subject-centred, while that in (57) is object-centred. (58) shows a subjectcentred headless relative clause introduced by anti:, while (59) shows an object-centred headless relative clause with an inanimate referent, introduced by antu::

Apapantilla Totonac

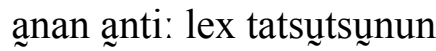

$\underset{\sim}{\operatorname{anan}}$ [anti: lex ta-tsutsu-nun $\left.\emptyset_{\mathrm{SUB}}\right]$

exist HREL much 3PL.SUB-Smoke-INDEF.OBJ

'There are many who smoke a lot.'

(Reid et al., n.d.)

ikpa:tsanqa:1 [aָntu: kiwãni]

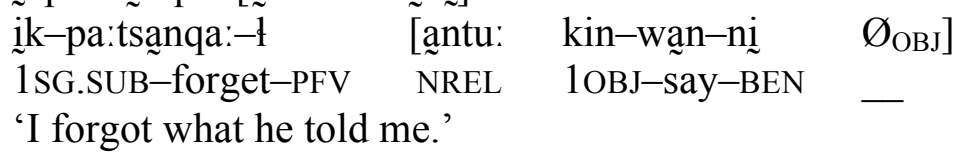

(Reid 1991: 58)

The relativizers here appear to be composed, at least etymologically, of $t i: t u$ : and what was historically a deictic element, *a a (cf. Upper Necaxa an 'medial non-demonstrative determiner').

Fronting of an argument within the relative clause is mentioned as a possibility in Reid et al. (1968), where the following example is given:

Apapantilla Totonac

anti: le:x lu:wa tasa:kwa iška:ma:skuxma: laqali:ya:n]

[anti: le:x lu:wa tasa:kwa išs-ka:-ma:-skux-ma: laqali:ya:n $\emptyset_{\text {SUB }}$ ]

[HREL much many peon PAST-CAUS-work-PROG daily

'the one who employed very many peons daily',

(Reid et al. 1968: 47)

The authors note that this type of fronting within a dependent clause is possible when the fronted element is "emphasized" or the fronted element contains a quantifier, as in (60) above. This

\footnotetext{
${ }^{11}$ The gloss in the original is 'who very many workers he-was-employing-them daily'.
} 
seems in line with the Upper Necaxa data, where fronting in the relative clause correlates with focalization.

While nothing is said explicitly in my sources about accessibility to relativization, examples culled from the lexical database compiled by missionaries from the Summer Institute of Linguistics (Reid et al., n.d.) include locative-centred relative clauses introduced by anta: 'where' (composed of *an and ta: 'where?'):

Apapantilla Totonac

(61) ka: li:xikwa nak ka $\underset{\sim}{a}: \underset{\sim}{a}$ :ivi:n anła: wi: misin

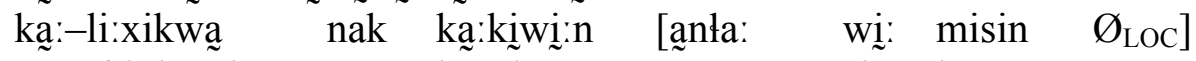

PLC-frightening LOC jungle LOCREL sit jaguar

'In the jungle where there there are jaguars (is) a frightening place.'

(Reid et al., n.d.)

There are also attestations of possessor-centred relative clauses:

Apapantilla Totonac

ma:qošamiši:ł wan puska:t anti: sputnił iškaman

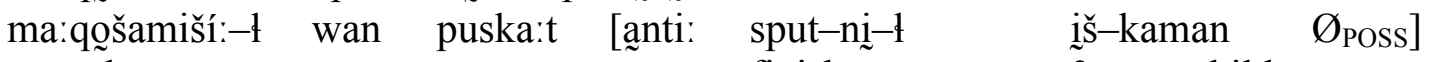

console-PFV DET woman HREL finish-BEN-PFV 3POSS-child

'He consoled the woman whose child died.'

(Reid et al., n.d.)

So it would seem that Apapantilla resembles Upper Necaxa in covering most of the Accessibility Hierarchy.

\section{Cerro Xinolatépetl Totonac}

The remainder of the Totonac languages fall into the South Central-Lowland division, which is comprised by two large branches encompassing an undetermined number of variants, Lowland and Sierra, and two individual languages, Cerro Xinolatépetl and Filomeno Mata, which appear to be peripheral to either of these branches. The most divergent of the two, Cerro Xinolatépetl, is virtually undescribed and what information we have about relatives in this language comes from the text in Andersen (2012), which contains two examples of relative clauses, one with an animate external head (63), and the other a headless relative with an inanimate referent (64):

Cerro Xinolatépetl Totonac

(63) išyanán ča :túm tăqQ: [tí: štewení laqóđes]

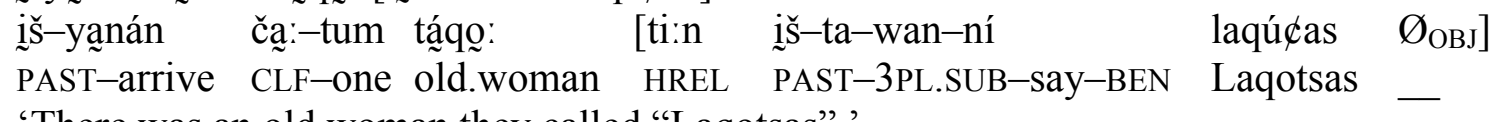

'There was an old woman they called "Laqotsas".'

(Andersen 2012: 182, line 2) 


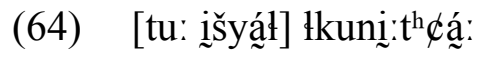

[tu:n iš-yán-li $\left.\quad \varnothing_{\text {SUB }}\right] \quad$ kuyú-ni:t=фá:

NREL PAST-go-PFV _ burn-PF=now

'The one who came out burned up.'

(Andersen 2012: 193, line 47)

These examples are, respectively, subject- (64) and object-centred (63), and make use of ti:n and tu:n relativizers.

Filomeno Mata Totonac

Filomeno Mata phonology and morphology are described in McFarland (2009), but this work does not address relativization; however, several examples of relative clauses do appear in the text in McFarland (2012). The example in (65) is an externally-headed object-centred relative introduced by the non-human relativizer, $t u u=$ (analyzed by McFarland as a clitic):

Filomeno Mata Totonac

(65) tapuuwán amá ntíxi [ ${ }^{\mathrm{n} t u u s ̌ m a a s ̌ t u m a ́ a k ~ . . . ~}$

ta-puuwán amá tíxi $\quad\left[\right.$ tuu=š-maa-štu-maa-kan $\left.\quad \varnothing_{\mathrm{OBJ}}\right]$

3PL.SUB-think this road NREL=PAST-CAUS-out-PROG-REFL _

'They think, this road that they were building ...'

(McFarland 2012: 276, line 31)

In (66) we see a headless subject-centred relative clause with an animate referent:

Filomeno Mata Totonac

[tiištamaatłaawaní mákina]

[tii=iš-ta-maa-tlaawan-nii

HREL $=$ PAST -3 PL.SUB - CAUS-walk-DAT

'the ones who drove the machines'

mákina $\left.\varnothing_{\mathrm{SUB}}\right]$

machine

(McFarland 2012: 274, line 22)

(67) shows a headless object-centred relative clause with an inanimate referent:

Filomeno Mata Totonac

[ntuuškaamaqskíma Pamá Paqsqawiní?i]

[tuu=š-kaa-maq-skin-maa amá aq-sqawi-ní?i $\left.\varnothing_{\mathrm{OBJ}}\right]$

NREL=PAST-PL.OBJ-body-ask-PROG this head-twist-AGT -

'what this devil asked them for'

(McFarland 2012: 275, line 34)

There are also some examples of locative-centred relative clauses such as that in (68): 
Filomeno Mata Totonac

para tsenatawašnán Pamá Pántsa ksípi [łaaštata Paqtseqóo mákina]

para tsi-na-ta-waš-nan amá ántsa k-sípi

if well-FUT-3PL.SUB-dig-INDEF.OBJ this here LOC-hill

[łaa $=\breve{s}-$ ta-ta-aq-tsi-qoo mákina $\left.\emptyset_{\text {LOC }}\right]$

LOCREL $=$ PAST -3 PL.SUB-MID-head-hide-TOT machine

'if they could dig on that hill where the machines got stuck'

(McFarland 2012: 272, lines 11-12)

The relative clause here is introduced by the locative relativizer $t a a=$, likely cognate with the relativizing element xa: used in the locative-centred relative clauses in Upper Necaxa in (36) and 0 above. In total, there are 31 instances of relative clauses in the text in McFarland (2012) and while this is a very small sample on which to make generalizations about constituent order, in all but one of the examples the relativizing clitic attaches to a verbal or non-verbal predicate, and in one case (p. 274, line 41) it attaches to an adverbial element glossed as 'now' preceding the verb, suggesting that there is at least a strong preference for relatives clauses to be predicate-initial.

\section{Lowland Totonac}

For the Lowland group, we have only information from Cerro del Carbón (a.k.a. Papantla Totonac), once again gleaned from texts (Levy 2012). In this language, we appear to find a structural distinction between externally-headed and headless relative clauses. An externallyheaded object-centred relative clause is illustrated in (69):

Cerro del Carbón Totonac

amá: sáqat [ni:ma ka:maqštaqni:ta]

amá: sáqat [ni:ma ka:-maqštaq-ni:tan-? $\left.\varnothing_{\mathrm{PO}}\right]$

that tall.grass REL PL.OBJ-leave-PF-2SG.SUB -

'that tall grass that you left'

(Levy 2012: 355, line 37)

The head of the relative clause here is sáqat 'tall grass', an inanimate noun; in (70) we see a subject-centred relative clause with a plural animate head:

(70) amá: čiškuwí:n [ní:ma ištalayá:na ištampí:n kíwi] mat tawán ...

$\begin{array}{lllll}\text { amá: } & \text { čišku-wí:n [ni:ma iš-ta-laya:-na } & \emptyset_{\text {SUB }} \\ \text { that } & \text { man-PL } & \text { REL } & \text { PAST-3PL.SUB-be.standing-ST.PL } & - \\ \text { iš-tampí:-n } & \text { kiwi] mat ta-wan-ya: } & \\ \text { 3POSS-under-NMLZR tree QTV 3PL.SUB-say.it-IMPF } & \end{array}$

'The men that were at the foot of the tree said ...'

(Levy 2012: 392, line 189)

In both examples, the relative clause is introduced by ni:ma, which varies neither with the animacy nor the number of the head of the relative construction. The texts contain 14 examples 
of externally-headed relative clauses, all of which are subject- or object-centred, and in all of which the relativizer immediately precedes the verb.

Headless relatives, on the other hand, use $t u$ : and $t i$, as in (71) and (72): ${ }^{12}$

Cerro del Carbón Totonac

... išli:mín [tu: išqa:łani:t]

iš-li:mín [tu: iš-qa:tán-ni:tán $\left.\emptyset_{\mathrm{PO}}\right]$

PAST-bring NREL PAST-steal-PF

'... (each) brought what he had stolen.'

(Levy 2012: 390-391, line 182)

(72) ... ti: iška:maqpa:waní:t

[ti: iš-ka:-maq-pa:wa-ni:tán $\left.\quad \emptyset_{\mathrm{PO}}\right]$

NREL PAST-PL.OBJ-CAUS-borrow-PF

'... those from whom he had borrowed.'

(Levy 2012: 417, line 62)

Both the examples here are object-centred, but a search through the 19 examples in the texts reveals that there are subject-centred clauses as well as clauses centred on what Levy (2002) analyses as secondary objects. All but one of the examples, shown in (73), has the embedded verb in absolute clause-initial position:

Cerro del Carbón Totonac

qašmata [tu: amá: kiłwama conejo] mat ltị:t tikšłi amá: ušpi

qašmat-ya: [tu: amá: kil-wan-mah conejo $\left.\varnothing_{\mathrm{PO}}\right]$ mat

hear.it:1/3-IMPF NREL that mouth-say.it-PROG:1/3 rabbit - QTV

ltị:t tikš-li amá: ušpi

IDPH fart-PFV that alligator

' $\mathrm{He}_{i}$ listens to what the rabbit is saying and, pbbt, the alligator ${ }_{i}$ farts.'

(Levy 2012: 464, line 255)

In (73), the verb kitwama 'say something' is preceded by a demonstrative amá: 'that'; however, it isn't entirely clear what the role of the demonstrative is in this sentence. One possibility is that it expresses the object (what the rabbit is saying), in which case this is an example of an internally-headed relative clause. Another possibility is that tu: amá: functions as a unit, forming a demonstrative relativizer. This is an interesting example and structures like these clearly merit further investigation.

\section{Sierra Totonac}

For the Sierra group, there are a few examples of relative clauses from Olintla Totonac found in the text in Tino (2012). On the whole, these resemble the Northern Totonac pattern found in Upper Necaxa and Apapantilla, in which both externally-headed and headless relative clauses are

\footnotetext{
${ }^{12}$ These are glossed by Levy as "lo.que" 'that which' and "el.que" 'the one that', respectively. I've glossed them as NREL and HREL to facilitate comparison with the other languages in the paper.
} 
introduced by a relativizer that varies according to animacy. Externally-headed constructions are illustrated in (74) and (75): ${ }^{13}$

\section{Olintla Totonac}

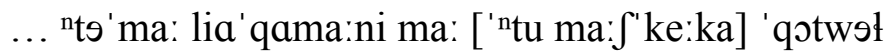

tamá: li:-qáma:n i ma: [tu ma:Jké:-ka $\left.\emptyset_{\mathrm{OBJ}}\right]$ qút-wa-ti

that INST-play JNCT PTCL NREL give-INDEF.SUB:PFV — drink-eat-PFV

'....he swallowed the toy that they gave him.'

(Tino 2012: 299, line 14)

(75) 'sqatą? 'nt $\int 0$ [nti: aqama:'nэni] ...

sqáta? t fo [ti qama:nán $\left.\emptyset_{\mathrm{SUB}} \mathrm{i}\right]$

baby PTCL HREL play:IMPF — JNCT

'... the baby that was playing ...'

(Tino 2012: 308, line 41)

These examples depart slightly from patterns we've seen previously in that the head noun is separated from the relativizer, $t u$ or $t i$, by elements glossed as "particles"; however, there are other examples in the text where the head noun is immediately adjacent to the relativizer (e.g., p. 309, line 42; p. 310, line 63). Note that we have both subject- (75) and object-centred (74) relative clauses here in these examples.

Headless relatives introduced by $t u$ and $t i$ are also attested:

\section{Olintla Totonac}

$$
\begin{array}{lllll}
\text { 'pus 'ntfo no' tluwja ['ntu kuni'ja:n] } & & & \\
\text { pus tfo na-tluwá-ja:-? } & \text { [tu } & \text { k-wan-ni-já:-n } & \emptyset_{\text {OBJ }} \\
\text { well PTCL } & \text { FUT-make-IMPF-2SG.SUB } & \text { NREL } & \text { 1SG.SUB-say-BEN-IMPF-2OBJ } & - \\
\text { 'Well then you'll do what I say.' } & & &
\end{array}
$$

(Tino 2012: 314, line 56)

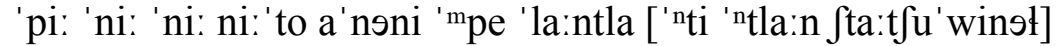

$$
\begin{aligned}
& \text { pi: ni: ni: ni:tó anán } \mathrm{i} \text { pe lá:ntla? } \\
& \text { since NEG NEG NEG be JNCT since how } \\
& \text { [ti tla:n } \left.\int-\text { ta:-tfuwínan- } \mathrm{ti} \quad \emptyset_{\mathrm{OBJ}}\right] \\
& \text { HREL well PAST-CMT-speak-PFV }
\end{aligned}
$$

'Since no, no, there was no one that she could talk with.'

(Tino 2012: 300, line 16)

Both of these examples are object-centred. Example (77) is of note in that it shows the embedded verb preceded by an adverbial, tla:n 'well', which is the source of the 'could' in the translation. This indicates that Olintla, like Huehuetla Tepehua and Upper Necaxa, preserves the pre-verbal positioning of adverbial elements inside relative clauses.

\footnotetext{
${ }^{13}$ The second word in example (74), li:qáma:n, is a nominalization of the verb qáma:n 'X plays'; the prefix li:- is an instrumental nominalizer, and is homophonous with the instrumental applicative li:-, as it is in several languages of the Central group.
} 
The nearby language of Huehuetla Totonac is described in Troiani (2004), which does not address relativization directly but provides a few examples in texts. Only headless relative clauses are attested at all for this language, and these make use of the $t u$ and $t i$ relativizers. Examples (78) illustrates a headless relative with an inanimate referent: ${ }^{14}$

Huehuetla Totonac

paks maqtimán [tuku kiłwámpa:t]

paks maqtti-ma-n [tu-ku kil-wan-pa:t $\left.\quad \emptyset_{\text {OBJ }}\right]$

all remove-IMPF-2OBJ NREL-still lips-say-IMPF:2SG.SUB

'She's taking away from you everything that you are saying.'

(Troiani 2004: 128, line 18)

Of note in example (78) is the combination of the relativizer with the suffix (most likely a clitic in morphosyntactic terms) $-k u$ 'still' (Fr. 'encore'). The corresponding element in Upper Necaxa, $=k u s$, is not attested in combination with the relativizers, though it combines with a wide range of other elements. While most of the examples in these texts show the relativizer combining with $-k u$, examples like (79) show that this is not obligatory:

Huehuetla Totonac

... maqkatsíy [tu lilaqatalawilikaní:t ktsi?]

maq-katsí-y [tu li:-laqa-tála-wíla-i-kan-ni:ta $\quad$ š-tsi? $\left.\quad \emptyset_{\text {OBJ }}\right]$

CAUS-know-ASP HREL INST-front-jam-sit-TRNS-SUB.SUPP-PF 3POSS-mother

'... he went to find out what his mother had been shut inside with.'

(Troiani 2004: 135, line 27)

The relative clause here has an inanimate referent, the knowledge of the Actor in the matrix clause. The example in (80) illustrates a headless relative clause with an animate referent:

Huehuetla Totonac

tsukúka ki:kškanáči [tikú ma:stawaníka], kawása tławakaní:t

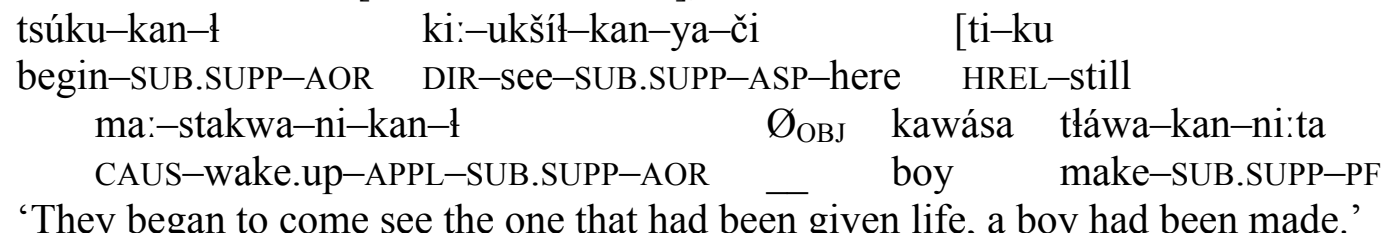

(Troiani 2004: 147, line 17)

The second clause at the end of this example, kawása tzawakani:t, is glossed in the original as a relative clause 'the boy that has been made' but is set off from the rest of the utterance by a prosodic boundary ("//") which I've represented in the transcription line as a comma; however, there is no relativizer in the Totonac and the indefinite actors in the first clause (the unspecified group that is coming to see the boy) and the final clause (the unspecified actor that made the boy) are not the same, whereas identity of unspecified actors would be expected within the confines of a single sentence. The possibility remains that this is indeed a paratactic relative construction of

\footnotetext{
${ }^{14}$ The translations of the glosses from French are mine. The relativizers are glossed as interrogatives in the original.
} 
the type seen in Misantla in (52), although to date no further evidence that this structure might exist in Huehuetla Totonac, or any other Sierra or Central Totonac language, has been found.

Turning to the Totonac spoken in Ozelonacaxtla, we find half a dozen examples of relative clauses in the text in Román Lobato (2012). These show the familiar Sierra pattern of externallyheaded and headless relatives introduced by relativizers that distinguish the animacy of the head of the relative clause, although the relativizers have a slightly different form. The inanimate relativizer (81) is given as tuku (cf. the Huehuetla form in (78) above), while the animate relativizer is $t i t f i(82)$ :

Ozelonacaxtla Totonac

... miliwti [tuku putsapa:t]

mi-liwat i [tuku putsa-pa:t

2POSS-food JNCT NREL look.for-PROG:2SG.SUB

'the food that you are looking for'

(Román Lobato 2012: 329, line 31)

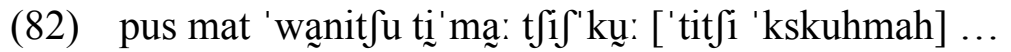

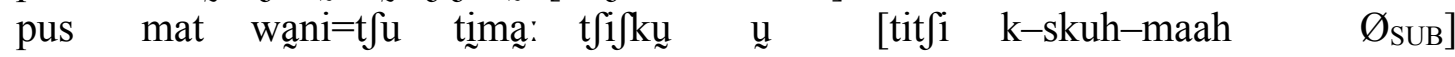

will QTV say=PTCL DIST hombre JNCT HREL PAST-work-PROG _

'Well, he said to the man that was working ...'

(Román Lobato 2012: 331, line 39)

There is currently not enough data to determine if these are actually unanalyzed combinations of a relativizer and some other element, as we saw in Huehuetla Totonac, or if these are in fact fixed forms derived diachronically from such sources.

The examples in (81) and (82) are object- and subject-centred, respectively. It also appears from an example given in Román Lobato (2008) that possessor-centred relatives are possible:

Ozelonacaxtla Totonac

ni par wá:ču li:talaqaputsíču čiškú: [tíči: špuská:ti šwánt]

ni par wá:=ču li:-ta-laqaputsí=ču čiškú-u [tiči-i

$\mathrm{NEG}$ if $\mathrm{FOC}=\mathrm{CL} \quad \mathrm{INST}-\mathrm{INCH}-$ worry $=\mathrm{CL}$ man $-\mathrm{JNCT}$ HREL $-\mathrm{JNCT}$

$$
\begin{aligned}
& \text { š-puská:t-i } \quad \emptyset_{\text {POSS }} \quad \check{s}-\text { wa-nit] } \\
& \text { 3POSS-woman-JNCT _ PAST-be-PF }
\end{aligned}
$$

'The man whose wife she was also didn't get into trouble.'

(Román Lobato 2008: 67)

This is an interesting example because the target of relativization is the possessor of the complement of the copular verb rather than of its argument.

Of particular note in the Ozelonacaxtla data is the following example, in which it appears that one of the arguments of the embedded clause intervenes between the verb and the relativizer: 


\begin{tabular}{|c|c|c|c|c|}
\hline $\begin{array}{l}\text { Ozelonacaxtla } \\
\text {... špuska:ti [tit }\end{array}$ & $\begin{array}{l}\text { otonac } \\
\text { i waja }\end{array}$ & wkah] & & \\
\hline š-puska:ti & {$\left[\operatorname{tit} \int 1\right.$} & waja & tlawa-kah & $\left.\varnothing_{\mathrm{PO}}\right]$ \\
\hline 3POss-woman & HREL & hawk & $\begin{array}{l}\text { make- } \\
\text { INDEF.SUB }\end{array}$ & \\
\hline
\end{tabular}

(Román Lobato 2012: 341, line 90)

In (84) we see that the noun wajg 'hawk', the object of the verb tlawa 'X makes Y into Z', ${ }^{15}$ immediately follows the relativizer tit $i$, separating it from the verb. This would appear to be an example of argument fronting inside the relative clause, although another possibility is that waja 'hawk' here is not an ordinary object but some kind of predicate complement occupying the preverbal slot normally taken by secondary predicates. This will have to remain an open question, pending further investigation.

Relative clauses in Zapotitlán Totonac (sometimes referred to in the literature as "Sierra" or "Highland Totonac") are described in an article by E. Aschmann (1984), although the scope of that paper and the range of constructions discussed under the heading of "relative clause" is somewhat broader than ours is here. Drawing on the descriptions in this paper and on unanalyzed examples contained in the lexical database compiled by H. Aschmann (n.d.a), it can be seen that Zapotitlán strongly resembles the other Sierra languages in most respects. Externally-headed relatives are introduced by $t i$ : and $t u$ : relativizers that distinguish animacy, and may be subject(85) or object-centred (86):

Zapotitlán Totonac

... sqata wa: [nti: taqalana: lakáčił]

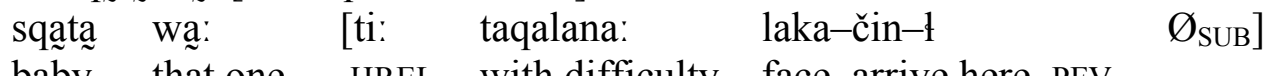

baby that.one HREL with.difficulty face-arrive.here-PFV -

'... a baby that was born with great difficulty'

(H. Aschmann, n.d.a)

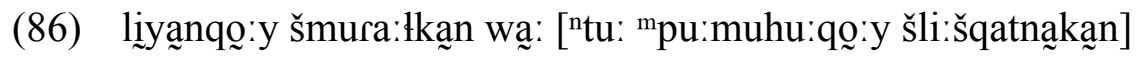

\begin{tabular}{|c|c|c|c|c|}
\hline $\begin{array}{l}\text { liyan-qa:-y } \\
\text { take-3PL-IMPF }\end{array}$ & $\begin{array}{l}\stackrel{\text { š-mura:1-kan }}{\text { 3Poss-bag-PL_PO }}\end{array}$ & wa: & [tu: & pu:muhu:-qQ:-y \\
\hline š-li:šqatna $-k$ & $\left.\varnothing_{\mathrm{OBJ}}\right]$ & & & \\
\hline
\end{tabular}

'They take along their shoulder bags in which they put their stakes.'

(E. Aschmann 1984: 20)

Of particular note in these constructions is the presence of the element $w a$ : intervening between the head noun and the relativizer. This is an extremely frequent feature of relative constructions in Zapotitlán, so much so that H. Aschmann (n.d.a) analyzes the relativizers as wa:nti: and

\footnotetext{
${ }^{15}$ Note that this analysis of the verb is based on the Spanish gloss given in the original, el que convertieron en gavilán. Another possibility, suggested by the fact that the cognate verb tławá ' $\mathrm{X}$ makes $\mathrm{Y}$ ' in most other Totonac languages is only bivalent, is that the relative is more accurately rendered as "the wife of the hawk that was made (i.e., created)". In this case, we would have an example of a possessor-centred internally-headed relative clause.
} 
wa:ntu:, respectively; however, there are examples (see (92) below) where the relativizer appears without wa: and in E. Aschmann's (1984) article wa: is treated as a separate focus particle. ${ }^{16}$ Comparison with probable cognates in other Totonacan languages shows that this element is likely derived from a demonstrative element of some kind.

E. Aschmann's article also provides examples of locative-centred (87) and possessor-centred (88) relative clauses:

\section{Zapotitlán Totonac}

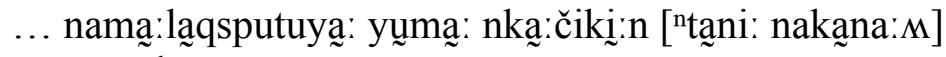

na-ma:-laqusput-u:-ya: $\quad$ yuma: $\quad n=k a: c ̌ i k i: n$

FUT-CAUS-expire-CAUS-IMPF:2SG.SUB that.thing LOCREL=town

["tani: na-k-an-a:-M$\quad \emptyset_{\text {LOC] }}$

LOCREL FUT-1SG.SUB-go-IMPF-1PL.SUB

'... you will destroy that village we are going to.'

(E. Aschmann 1984: 20)

(88) na: tiantsax ta্sanikan yựa wa্র: [nti: ščišku]

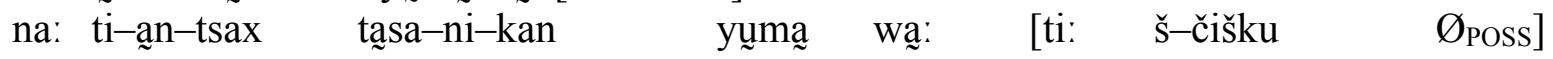

also PATH-go-now call-BEN-INDEF.SUB this.one that.one HREL 3POSS-husband

'Someone also went to call the one who was her husband.'

(E. Aschmann 1984: 14)

The locative relativizer in (87) is notable in that it differs from the locative interrogative, $n i$ 'where?', whereas Upper Necaxa uses the same form to introduce locative relatives as it uses to question locations.

Headless relatives appear to be built along similar lines to externally-headed constructions. Headless subject-centred relative clauses with animate and inanimate referents are illustrated in (89) and (90):

\section{Zapotitlán Totonac}

wa: [nti: tsukuqo:ł li:pa:wanqo:y Jesús]

wa: [ti: tsuku-qQ:-1 li:-pa:wan-qQ:-y Jesús $\left.\varnothing_{\mathrm{SUB}}\right]$

FOC HREL begin-3PL-PFV INST-feel.trust-3PL-IMPF Jesus -

'Those that began to trust in Jesus.'

(H. Aschmann, n.d.a)

(90) wạ: [ntu: šmaktawakaja

wåa: $\quad\left[\right.$ tu: $\left.\check{\text { š-mak-ta-waka }- \text { y }} \quad \varnothing_{\text {suB }}\right]$

that.one NREL PAST-body-DCS-be.high-IMPF

'what was on his body (i.e., what he was wearing)'

(H. Aschmann, n.d.a)

\footnotetext{
${ }^{16}$ I have adjusted the transcription and analysis of the examples from H. Aschmann in (85) and onwards in accordance with E. Aschmann's interpretation. It should also be noted that while E. Aschmann refers to wa: as a "focus particle" in her text, she glosses it as 'that one' in her interlinearizations, a practice I've followed here. Given that E. Aschmann only provides word-level glosses, I have also expanded her analyses by parsing out morphemelevel constituents of words.
} 
Headless object-centred relative clauses are shown in (91) and (92):
Zapotitlán Totonac
(91) kit nakputsaniya:n [nti: nata:tapu:čuwaya]
$\begin{array}{lllll}\text { kit } & \text { na-k-putsa-ni-ya:-n } & \text { [ti: } & \text { na-ta:tapu:čuwa-ya } & \left.\varnothing_{\text {OBJ }}\right] \\ \text { I } & \text { FUT-1SG.SUB-look.for-BEN-IMPF-2OBJ } & \text { HREL } & \text { FUT-marry-IMPF:2sG.SUB } & \end{array}$
'I will look for the one whom you will marry.'

(E. Aschmann 1984: 9)

(92) ni ma:Хa:ni:1 [ ${ }^{\mathrm{n}} \mathrm{tu}:$ špuwani:t]

$\begin{array}{lllll}\text { ni } & \text { ma:- } \chi \text { awa-ni:-1 } & \text { [tu: } & \check{\text { s}} \text {-puwan-ni:t } & \emptyset_{\text {OBJ }}\end{array}$

'He did not accomplish what he had planned.'

(E. Aschmann 1984: 3)

Note that these last examples lack the focus particle wa: and show clearly that it is a separable element from the relativizers $t i$ : and $t u$ :

A final example drawn from E. Aschmann (1984) is of special interest here, as it seems to be an example of both a fronted argument and of an internally-headed relative clause: ${ }^{17}$

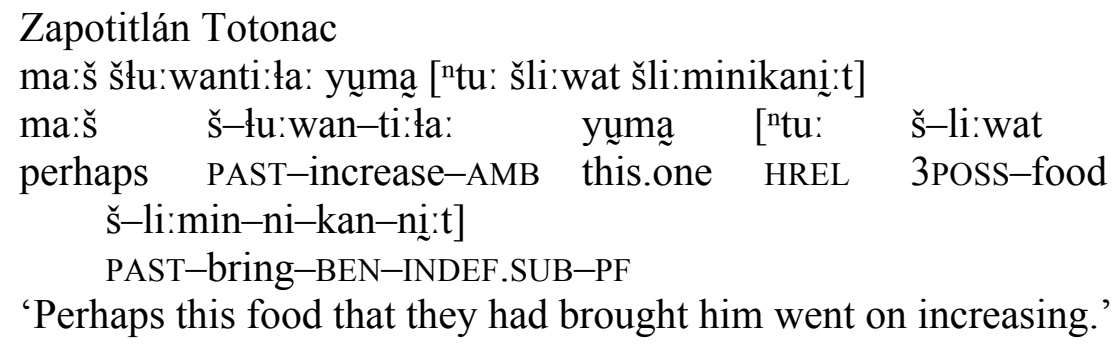

(E. Aschmann 1984: 14)

Here we see a fronted object, šli:wat 'his/her food', immediately following the relativizer; this object is also the referent of the clause itself, making the construction internally-headed. Its positioning in front of the verb most likely implies some sort of focalization. It is unclear at this time whether the element yumg 'this one' would also be considered an external-head (rather than a determiner introducing a headless NP), although this seems likely given that in other examples this word appears to be a demonstrative pronoun. If this analysis turns out to be correct, (93) would be an example of what Dryer (2013) refers to as a "double-headed" relative clause, a pattern attested in only one of the 824 languages in his sample.

The last language for which any information is available is Coyutla Totonac, although the data in this case is somewhat problematic. The lexical database complied by H. Aschmann (n.d.b) contains on the order of 1,800 examples of what appear to be relative clauses; however,

\footnotetext{
${ }^{17}$ My assessment of this structure differs from E. Aschmann's, who treats it as a recursive embedding in which the verb following šlirwat 'his food' is subordinated in a paratactic relative construction; however, the gloss given by E. Aschmann, 'perhaps this food of his which they brought to him just kept on increasing', does not show recursive embedding (i.e., she does not gloss it as 'this one that is his food that they had brought him').
} 
these sentences are all translations of isolated lines of Biblical text, rather than spontaneous spoken language. Thus, while we can draw inferences about structure from these sentences, conclusions about certain things such as constituent order, which is highly susceptible to influence from the source language during translation, must be considered extremely tentative.

In Coyutla, there seem to be two sets of relativizers used for forming relative clauses. The overwhelmingly most common strategy is the use of wa:ntu and wa:nti as inanimate and animate relativizers, respectively, in both externally-headed and headless constructions. The following example illustrates both an externally-headed and a headless subject-centred relative: ${ }^{18}$

Coyutla Totonac

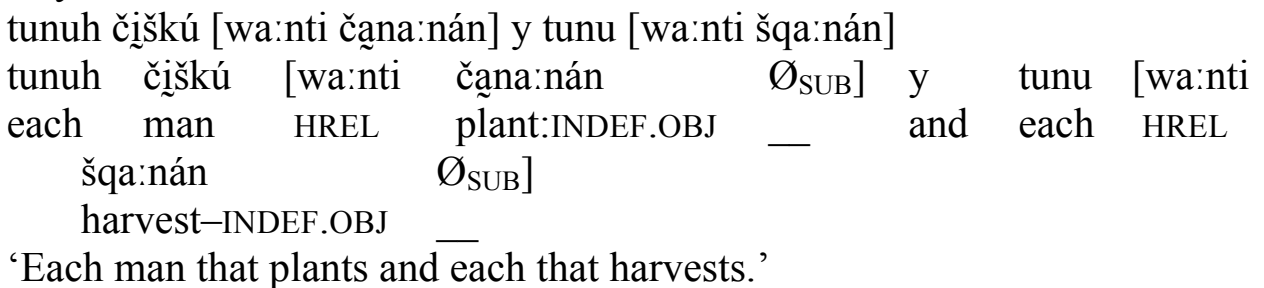

(H. Aschmann, n.d.b)

The structures here appear to be very much in line with what we have seen so far in Sierra and Northern Totonac. On closer analysis, the animate relativizer (as in Zapotitlán, see 0 above) appears to be, at least etymologically, composed of separate elements, and indeed wa ti is given an entry and defined as a relative pronoun in the database, which also contains five examples of relative clauses introduced by this pair of elements. $w a$ itself is defined as a pronoun meaning 'that which is referred to' and is cognate with demonstrative elements across the language family (including the Zapotitlán wa:). The $/ \mathrm{n} /$ in wa:nti is quite probably an effect of prenasalization at a phrase boundary, which is a common prosodic feature in Sierra Totonac languages (P. Levy, p.c.; see also McQuown 1990, Román Lobato 2008, McFarland 2009, and the examples from Filomeno Mata and Sierra languages above). This hypothesis is supported by the lengthening of the vowel, another prosodic feature of certain phrase boundaries. Whether distribution of wa:nti and wa $t i$ is predictable on prosodic grounds, in which case it is a synchronic alternation, or if wa:nti has been lexicalized as a unit and the choice is governed by other principles is a question that will have to wait for access to more naturalistic spoken data.

Some support for the wa:nti form being lexicalized comes from an examination of the inanimate relativizer wa:ntu, which does not show any alternation with a hypothetical wa tu form (nor is wa tu given an entry in H. Aschmann's database). (95) and (96) show, respectively, an externally-headed and a headless subject-centred relative clause introduced by wa:ntu:

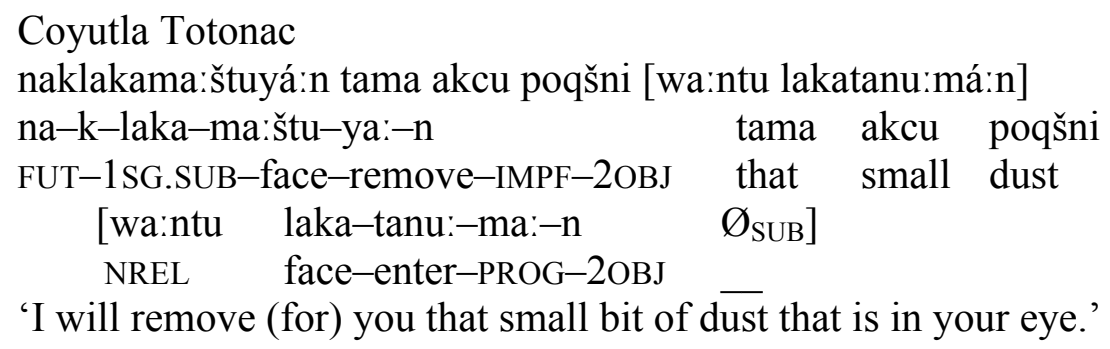

(H. Aschmann, n.d.b)

\footnotetext{
${ }^{18}$ The interlinearizations and translations from the Spanish are mine.
} 


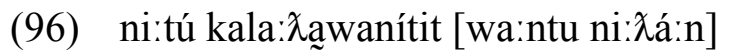

\begin{tabular}{|c|c|c|c|c|}
\hline ni:tú & ka-la:- 入awa-ni-tit & [wa:ntu & ni:- $-\chi a: n$ & $\varnothing_{\mathrm{SUB}}$ \\
\hline way & OPT-RCP-make-BEN-2PL.SUB & NREL & NEG-good & \\
\hline
\end{tabular}

(H. Aschmann, n.d.b)

The embedded clause in (96) is a copular clause with an adjectival predicate.

In addition to subject-centred relative-clauses like those above, object-centred relative clauses of both types are attested, as are a few possessor-centred relatives such as (97), introduced by wa:ntu, and (98), introduced by wa:nti:

\section{Coyutla Totonac}

(97) la:ta ča tuku ya ki⿱wi wa:ntu ni: tawakay štawákă ka $\underset{\sim}{\sim}$ :mi:kán

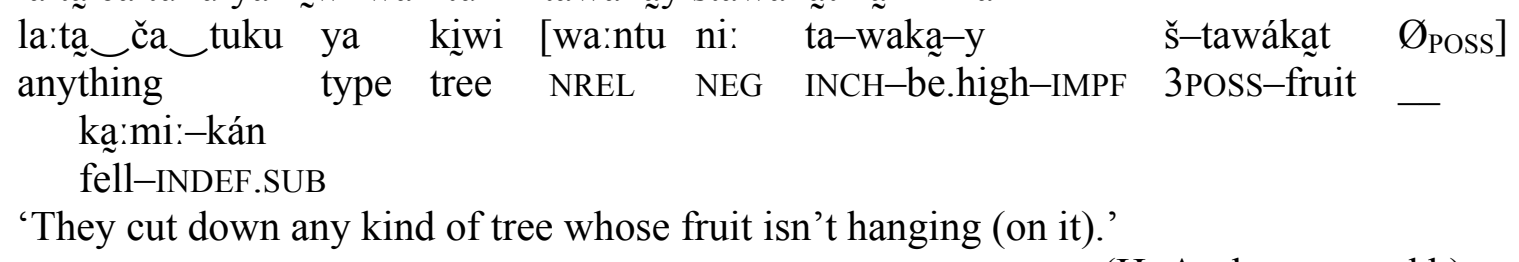

(H. Aschmann, n.d.b)

(98) ... lakčiškuwí:n [wa:nti lakli:škahnit štapuwa:nkåán]

$\begin{array}{lllll}\text { lak-čišku-wi:n } \quad \text { [wa:nti lak-li:škahnit } & \stackrel{\text { š-tapuwa:n-kan }}{\sim} & \left.\emptyset_{\text {POSS }}\right] \\ \text { PL-man-PL } & \text { HREL } & \text { APL-horrible } & \text { 3POSS-thought-PL.PO } & - \\ \text { '... people whose thoughts are bad' } & & \end{array}$

(H. Aschmann, n.d.b)

Thus it seems that Coyutla has access to nearly the full range of the Accessibility Hierarchy.

Another feature of the Coyutla data is that there are a few examples of object-centred relative clauses in which the subject precedes the embedded verb, such as the externally-headed relative in (99):

\section{Coyutla Totonac}

a:ma tapáški:t [wa:ntu Dios kinka:ma:škĩ:ni:tán]

a:ma tapáški:t [wa:ntu Dios kinka:ma:škị:ni:tán

that love NREL God 1OBJ-PL.OBJ-give-PF-2OBJ _

'the love that God has given us'

(H. Aschmann, n.d.b)

In this example, the verb kinka:ma:ški:ni:tán 's/he has given it to us' is preceded by its subject, Dios 'God'. In (100), the verb wanipa:t 'you are saying it about him/her' is preceded by a second-person singular independent pronoun, wiš: 
Coyutla Totonac

... klaqapasa [wa:nti wiš wanípa:t]

$\begin{array}{lcclc}\text { k-laqapas-a } & \text { [wa:nti } & \text { wiš } & \text { wan-ni-pa:-t } & \emptyset_{\text {PO }} \\ \text { 1SG.SUB-know-IMPF } & \text { HREL } & \text { you } & \text { say-BEN-PROG:2SUB-2SG.SUB } & \end{array}$

'... I know the person you are referring to.'

(H. Aschmann, n.d.b)

As noted above, however, this data should be handled cautiously when it comes to drawing conclusions about possible word order, given that these sentences are translations, which even in fluent bilinguals are notoriously vulnerable to interference from the source language when it comes to constituent ordering. Nevertheless, sentences like these strongly suggest that Coyutla permits the fronting of arguments inside relative clauses.

Another relative or relative-like construction that turns up with some frequency in the Coyutla data is a construction introduced by tiku (animate) or tuku (inanimate):

Coyutla Totonac

tiku la šapu:ł šqała:nán

tiku la ša-pu: $\quad$ š-qała:-nan

someone how DTV-first PAST-Steal-INDEF.OBJ

'one that before (now) would steal'

(H. Aschmann, n.d.b)

(102) ni: lay tuku tsę:q đawakán

ni: la-y tuku tse:q גawa-kan

NEG do-IMPF something hidden make-INDEF.SUB

'There is nothing that is done in secret.'

(H. Aschmann, n.d.b)

These constructions are invariably translated as relative clauses and seem to consistently have an indefinite reference. Both tiku and $t u k u$ combine with the negative $n i$ : to form the expressions for 'nobody' and 'nothing', indicating that they are likely, at least in origin, indefinite pronouns. If these are indeed native relative clauses (as opposed to non-native formations created under the pressure of translating Biblical text), this is the first evidence we have of a distinction between headless relative clauses with definite and indefinite referents.

\section{Conclusions: Diachronic and synchronic perspectives}

Although the data surveyed in the preceding sections is fragmentary and, for many languages, we can only draw tentative conclusions based on a handful of examples, a family profile does seem to be emerging. It appears that all Totonacan languages can form externally-headed, postnominal relatives with a gap in the embedded clause. Headless relative clauses are also attested in all the languages surveyed. Externally-headed constructions seem to have access to a fairly broad range of the Accessibility Hierarchy: object-centred constructions are attested for all of the languages and, given that all of the languages for which numerous examples are available (Upper Necaxa, Apapantilla, Zapotitlán, and Coyutla) go down the hierarchy at least as far as possessor- 
centred constructions, it seem likely that this type of relative is not attested for the others simply due to the lack of data.

The presence of internally-headed relative clauses is unequivocally attested only in Upper Necaxa, although there are examples of what could be interpreted as internally-headed constructions in Misantla (52), Cerro del Carbón (73), and Zapotitlán (93) as well. Good evidence for argument fronting is seen in Upper Necaxa, Apapantilla, and Cerro del Carbón, and the data suggest that it may be possible in Misantla, Ozelonacaxtla, Zapotitlán, and Coyutla. Given that fronted arguments in languages where we do have evidence for it are subject to rather specific discourse-conditions, it again seems probable that fronting is also an option in some or all of the other languages in the family, and we might expect it to turn up as more data comes in.

The only structural distinction that correlates with a major phylogenetic grouping is whether or not the relative clause is introduced by a dedicated relativizer that agrees in animacy with its head. In Tepehua, relative clauses are introduced by an invariant element homophonous with a determiner (or one of the determiners) used in noun phrases, whereas Central Totonac languages make use of the $t i: t u$ : relativizers (or variants of these). Misantla, which occupies a coordinate branch with respect to Central Totonac, seems to have both types of structure, although there are only clear attestations of the dedicated relativizers being used in what are either headless relative constructions or are complement clauses resembling English embedded questions. It is also of interest that in Cerro del Carbón, our only representative of the Lowland group, there appears to be a structural distinction between externally-headed and headless relative clauses as well, with the $t i: / t u$ : relativizers again found in the headless constructions. In Cerro del Carbón, however, the element used to introduce externally-headed relatives does not appear to be part of the regular determiner system, and so this may not be a cognate construction with the Misantla or Tepehua determiner-headed relatives, but rather a later innovation - at least as far as as the origins of the relativizer are concerned. However, the use of the $t i: t u$ : forms in Cerro del Carbón headless relatives does seem clearly linked to the use of these forms in the Misantla "embedded question" pattern.

The link to embedded questions is also apparent in the diachronic origins of the $t i: t u$ : relativizer itself. As noted above, the Upper Necaxa relativizers are homophonous with the animate/inanimate interrogative pronouns in that language, and a look across the family (Table 1 below) shows that this is a consistent pattern. A $t i: t u$ : animacy distinction in the interrogatives is found in all the Totonac languages and traces of it remain in Tepehua; in much of the Totonac branch of the family, the forms of the relativizers and interrogatives are, if not identical, then clearly etymologically related. Indeed, as seen in Table 1, the interrogatives and relativizers are homophonous in five of the languages of the Central Totonac group-Upper Necaxa, Filomeno Mata, Olintla, Huehuetla, and Zapotitlán. In Cerro del Carbón, the interrogatives are tiku and tuku (cf. the Ozelonacaxtla inanimate relativizer, tuku), and the Coyutla relativizers used in indefinite relatives in (101) and 0 above are likely based, at least diachronically, on $t i$ : and $t u$ : as well. In Apapantilla, the animate interrogative is $t i$ : and the inanimate is tuču:-again, the latter form seems likely due to the combination of $t u$ : and some other element (cf. Upper Necaxa tu: ču? 'what (thing)?'). In Misantla, the 'what?' interrogative is tu: and the 'who?' interrogative, $t i: y u$, is almost certainly derived from $t i$ : The Tepehua languages for the most part seem to have preserved only $t i$ : interrogative forms, erasing the animacy distinction in questions; however, both the Pisaflores (MacKay and Trechsel 2012a) and Tlachichilco (Watters n.d) lexica list 'what?' interrogatives that appear to contain $t u$. It seems a fairly trivial step at this point to posit 
both *ti: and *tu: interrogatives and an animacy distinction in information questions for protoTotonacan.

\begin{tabular}{|c|c|c|c|}
\hline & & Interrogative & Relativizer \\
\hline \multirow{3}{*}{ TEPEHUA } & Tlachichilco & $\begin{array}{l}\text { tisúnča 'what?' } \\
\text { (also tučičúnča 'what?') }\end{array}$ & \multirow{3}{*}{ DET } \\
\hline & Huehuetla & $\begin{array}{l}\text { tirs 'what?' } \\
\text { ti:či 'who?' }\end{array}$ & \\
\hline & Pisaflores & $\begin{array}{l}\text { ti:su 'what?, who?' } \\
\text { (also turtsi:patsun 'what?') }\end{array}$ & \\
\hline \multirow{9}{*}{ TOTONAC } & Misantla & $\begin{array}{l}\text { tizyu 'who?' } \\
\text { tu: 'what?' }\end{array}$ & $\begin{array}{l}\mathrm{DET} / \varnothing \\
\operatorname{tu}(t)\end{array}$ \\
\hline & Apapantilla & $\begin{array}{l}\text { ti: 'who?' } \\
\text { tuču: 'what?' }\end{array}$ & anti: \\
\hline & Upper Necaxa & $\begin{array}{l}\text { ti: 'who?' } \\
\text { tu: 'what?' }\end{array}$ & ti: \\
\hline & Filomeno Mata & $\begin{array}{l}\text { ti: 'who?' } \\
\text { tur: 'what?' }\end{array}$ & ti: \\
\hline & $\begin{array}{l}\text { Olintla, } \\
\text { Huehuetla }\end{array}$ & $\begin{array}{l}t i \text { 'who?' } \\
t u \text { 'what?' }\end{array}$ & ti \\
\hline & Ozelonacaxtla & $\begin{array}{l}\text { [no data] } \\
\text { tu 'what?' }\end{array}$ & $\begin{array}{l}\text { tiči } \\
\text { tuku }\end{array}$ \\
\hline & Zapotitlán & $\begin{array}{l}\text { ti: 'who?' } \\
\text { tu: 'what?' }\end{array}$ & $\begin{array}{l}\text { ti: } \\
\text { tu: }\end{array}$ \\
\hline & Coyutla & $\begin{array}{l}\text { tíku 'who?' } \\
\text { túku 'what?' }\end{array}$ & $\begin{array}{l}\text { wainti } \\
\text { waintu }\end{array}$ \\
\hline & Cerro del Carbón & $\begin{array}{l}\text { tíku 'who?' } \\
\text { túku 'what?' }\end{array}$ & $\begin{array}{l}\text { ti: } \\
\text { tu: } \\
\text { ni:ma }\end{array}$ \\
\hline
\end{tabular}

Table 1: Totonacan interrogative pronouns and relativizers

The diachronic origins of the $t i: t u$ : relativizers in interrogative pronouns naturally returns us to the issue, raised at the beginning of this paper, of the nature of the relativizers in the synchronic grammars of the various languages. Given the familiarity of languages where interrogatives are homophonous with genuine relative pronouns, it might be tempting to declare "once a pronoun, always a pronoun." However, things aren't quite that simple. While the $t i: / t u$ : relativizers do seem pronoun-like in that they encode a category, animacy, that belongs to nouns, it should be noted that the animacy distinction (human/non-human) here is a semantic category that manifests itself only in the interrogatives/relativizers and can not be considered an inflectional category of Totonacan nouns or pronouns in general. On the other hand, case, the category most commonly associated with relative pronouns in the literature (e.g., Comrie and Kuteva 2013), is an inflection of nouns or pronouns in those languages that are analyzed as having relative pronouns. The main reason that case-marking is often considered diagnostic for relative pronouns is that case gives overt clues to the syntactic relations between the pronominal element and a governing verb-specifically, for relative pronouns, the case-marking reflects the argument relations between the head of the relative construction and the verb in the embedded 
clause. Complementizers, however, are not arguments of the verbs contained by the clauses they introduce, nor are they expected to be affected by the embedded verb's government pattern: their primary function is to govern the subordinated clause as a whole, to signal subordination, and, frequently, to demarcate one of the boundaries of the subordinated construction.

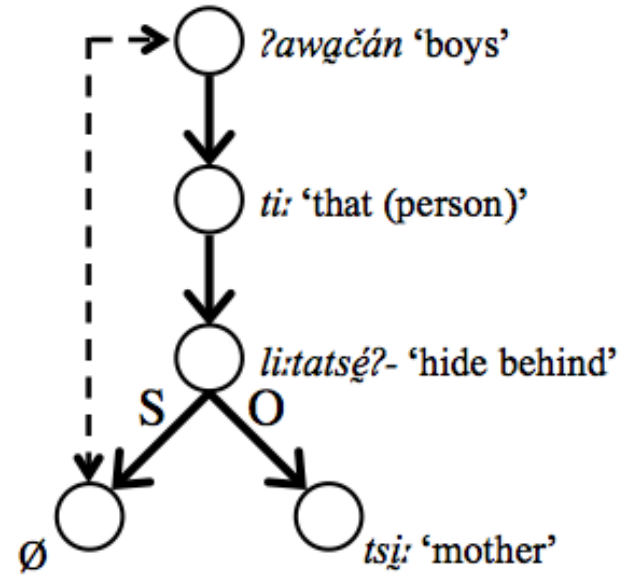

externally-headed with complementizer

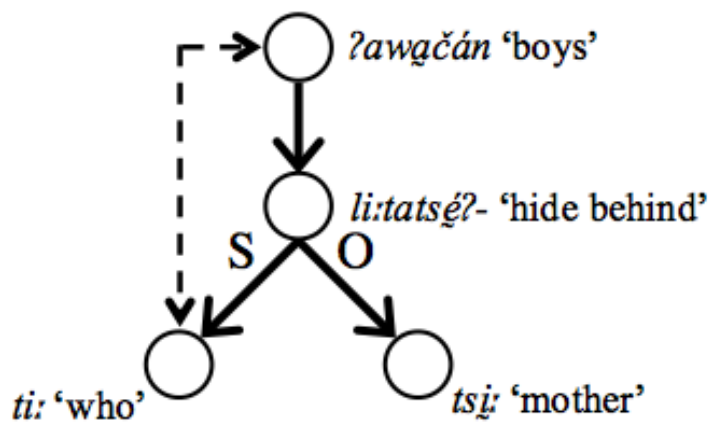

externally-headed with relative pronoun

Figure 3: Difference between a relative pronoun and a complementizer

In the Totonacan languages, unfortunately, case is non-existent and so its presence/absence can not be used as diagnostic for relative pronouns. We can, however, apply some basic syntactic reasoning to the problem, allowing us to consider the issues at a level other than the surface expression of morphological categories like case. Figure 3 presents two possible analyses of the sentence in (103) - an externally-headed, subject-centred relative clause-using a simplified dependency tree to represent the syntactic structure:

$$
\begin{aligned}
& \text { Upper Necaxa Totonac } \\
& \text { Pawą̌ăán [ti: tali:tatsếPa ịstsị:kạ́n] } \\
& \text { Pawačáa } \left.n \text { [ti: ta-li:-ta-tsę?-a ǐš-tsi:-kan } \quad \varnothing_{\text {SUB }}\right] \\
& \text { boy-PL HREL 3PL.SUB-INST-DCS-hide-IMPF } \\
& \text { 3POSS-mother-PL.PO } \\
& \text { 'those boys that hide behind their mother('s skirts)' }
\end{aligned}
$$

The trees used in Figure 3 and below are roughly equivalent to surface-syntactic trees used in Meaning-Text Theory (Mel'čuk 1988), where circles indicate lexical items, solid arrows show head-dependant relations, and the dashed arrow represents co-referentiality between the head of a relative clause and the relativized element in the embedded clause. The $\varnothing$ represents an elided element. The tree on the left side of Figure 3 treats $t i$ : as a complementizer, a subordinating element that governs the embedded clause and links it to the noun being modified. The head of the relative construction - the modified noun, Pawačán 'boys' - is overt, and the co-referential target of relativization is gapped inside the embedded clause. The tree on the right treats the human relativizer ti: as a relative pronoun occupying an argument slot-subject $(\mathrm{S})$ - of the embedded verb. The verb itself depends directly on the head of the relative construction, which is co-referential with the pronoun in the relative clause. In contrast, the complementizing $t i$ : in 
the tree on the left side of Figure 3 is not considered a pronoun and is not coreferential with the head of the relative construction, although it agrees with it in animacy.

Practically-speaking, either of the trees in Figure 3 seems to be a plausible representation of (103), and there is little to choose between the two. However, the same cannot be said of the two structures in Figure 4, which represent (104), the internally-headed version of (103):

Upper Necaxa Totonac

[ti: tali:tatsę́fa Pawačắn isstsị:kạ́n]

$\varnothing \quad$ [ti: ta-li:-ta-tsę?-a Pawačáa $-\mathrm{n}$ iš-tsi:-kañ $]$

HREL 3PL.SUB-INST-DCS-hide-IMPF boy-PL 3POSS-mother-PL.PO

'those boys that hide behind their mother('s skirts)'
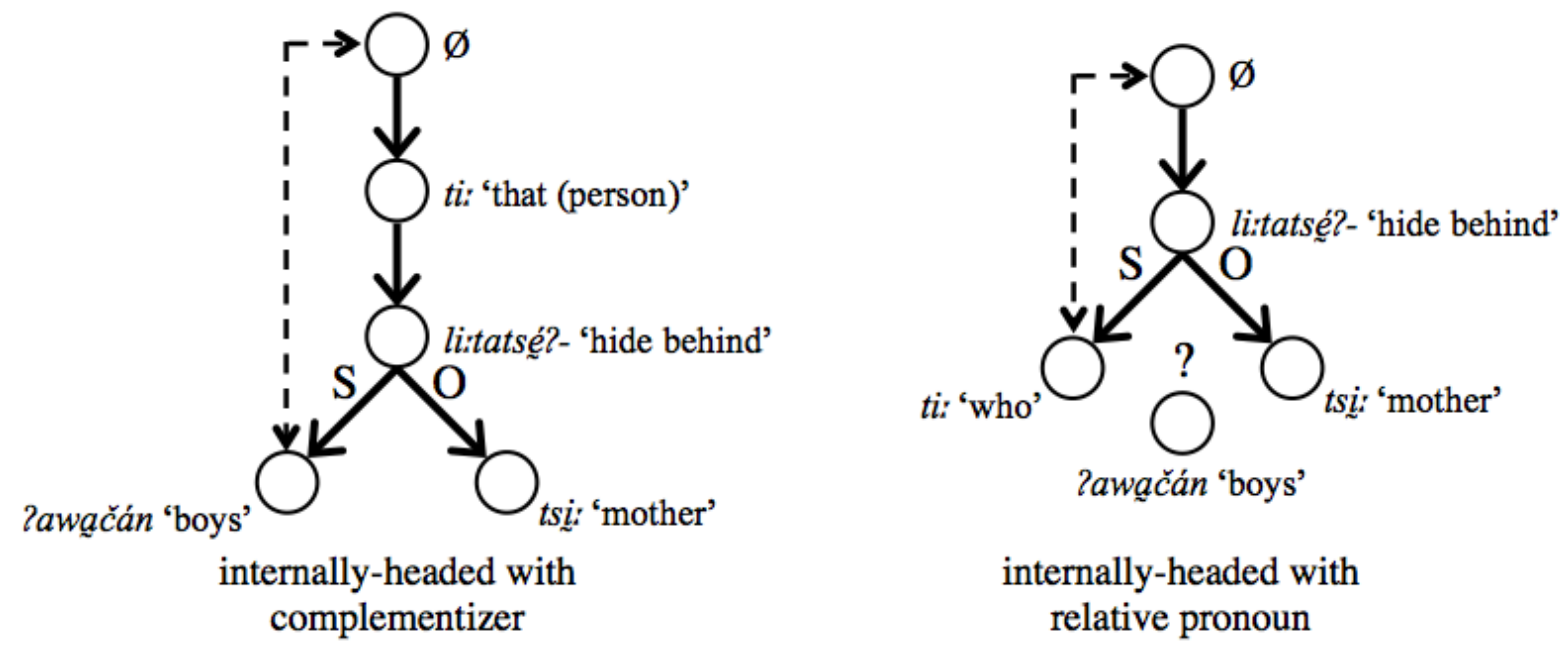

Figure 4: Internally-headed relative clauses

The analysis that treats $t i$ : as a complementizer, shown in the tree on the left side of Figure 4, offers a fairly straightforward treatment of the internally-headed construction exactly parallel to the tree on the lefthand side of Figure 3-only in this case it is the external head of the relative clause that is elided and the argument of the embedded verb is left in place (cf. a similar proposal, couched in different terms, by Cole 1987). The relative-pronoun analysis of the internally-headed construction on the right side of Figure 4 is more problematic. As a relative pronoun, $t i$ : would be expected to fill an argument position of the embedded verb; however, as shown in the diagram, this leaves nowhere for the nominal head of the construction to go, the valency of the embedded verb being "saturated" by the relative pronoun. While it might be possible to invent additional (and rather abstract) syntactic rules for argument-doubling or allowing the linearization of an external head inside of a relative clause, these would be ad hoc rules invented solely for the purposes of representing a single structure, whereas the complementizer analysis of the relativizers serves to model both the sentences in (103) and (104) without recourse to any additional machinery.

Analyzing the $t i: t u$ : relativizers as complementizers effectively reduces the distinction between externally-headed and internally-headed relative clauses to a choice made by speakers as to which of the two lexical expressions of the head of the relative clause to elide - the internal argument of the embedded verb (the gapping strategy obligatorily applied in languages like 
English), or the external head of the larger NP containing the relative clause. As shown in Figure 5 , this approach also extends itself very naturally to representing headless relatives such as (105):

Upper Necaxa Totonac

[ti: tali:tatsę́Pa istsi:kán]

$\varnothing \quad$ [ti: ta-li:-ta-tsę?-a $\quad \varnothing_{\text {SUB }}$ iš-tsi:-kañ]

HREL 3PL.SUB-INST-DCS-hide-IMPF _ 3POSS-mother-PL.PO

'those that hide behind their mother('s skirts)'

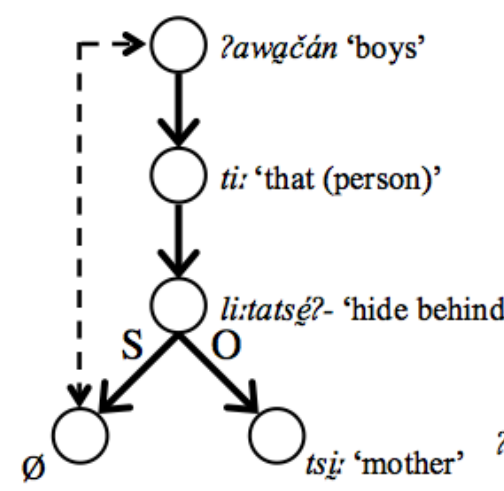

externally-headed with complementizer

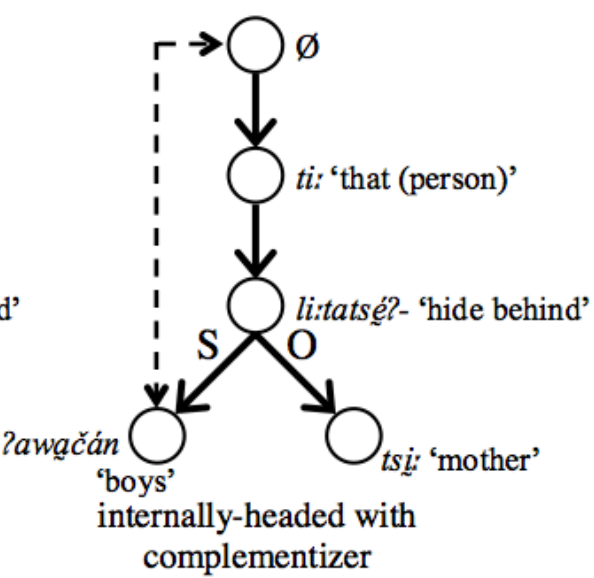

complementizer



headless with complementizer

Figure 5: Externally-headed, internally-headed, and headless relatives

In the headless construction, both the external and internal expressions of the head of the relative clause are elided, something that seems perfectly natural for a Totonacan language which routinely elides NPs in a wide variety of contexts.

The complementizer analysis of the relativizers in Figure 5 neatly models all three types of Upper Necaxa relative clauses, and could easily be extended to double-headed clauses such the Zapotitlán sentence in (93) above, which would simply be an example of a construction in which neither external head nor internal argument was elided (or perhaps one in which the external head is pronominalized). Treating the relativizers as complementizers reduces the differences between all of these structures to a single parameter, selection of which NP or NPs to elide from the surface form of the sentence. How this choice is made is still an open question, but is likely to depend on the same considerations of information/communicative structure that govern the elision (and ordering) of NPs and other constituents in other contexts.

An added benefit of thinking of the $t i: t u$ : elements as complementizers is that it suggests a very natural diachronic progression from an original proto-Totonacan scenario where *ti: and *tu: were interrogative pronouns and, possibly, used as complementizers in the embedded question type of subordinate clause illustrated by the Misantla examples in (54) and (55) above. At this stage, relativization would have been accomplished using determiners or demonstrative elements, as it is in Tepehua and Misantla today. The subordinate structures introduced by interrogatives could then have passed through an intermediate stage where they were more generalized as a means of forming sentential arguments - essentially, a syntactic means of "nominalizing" clauses, creating predications with nominal referents-while adnominal modification by clauses continued to be carried out by determiner-headed constructions. This is possibly the situation as it stands in Misantla. Cerro del Carbón would then represent an 
innovation on this pattern whereby it uses the $t i: / u$ : constructions as arguments but has evolved another element as a specialized subordinator for clauses used in adnominal modification. The final step in the progression would be the generalization of the $t i: / t u$ : subordinating pattern from argument-formation to modification, replacing the determiner-headed relative construction altogether and giving us the pattern seen today in Northern and Sierra, as well as in Cerro Xinolatépetl and Filomeno Mata. If correct, this progression means that, perhaps counterintuitively, the construction used in adnominal modification in most Central Totonac languages has its origin in a construction that was once used exclusively to form headless relatives (or, more accurately, the functional equivalent of headless relatives-syntactically nominalized subordinate clauses with nominal referents). The diachronic origins of the relativizers in interrogatives also help to explain the somewhat anomalous (though not unprecedented, e.g. Zwart 1993, 2006; Haegeman and van Koppen 2012; Lewis 2013) phenomenon of agreement in Upper Necaxa complementizers.

All of this is, of course, still highly speculative, and the game is still in its early stages, given the incomplete information we have about relatives and other types of subordination in so many of the languages in the family. Of particular importance would be some clarification of the situation in Misantla - which could potentially represent an important intermediate stage of development - and some further insight into the origins of the Cerro del Carbón relativizer ni:ma, as well as its distribution in other languages of the Lowland Totonac group. The presence of internally-headed relative clauses has only been confirmed in two languages, Upper Necaxa and Zapotitlán - although these are attested in Coahuitlán Totonac (Moore 2016), and there are potential examples in Misantla, Cerro del Carbón, and Ozelonacaxtla as well. The possible development of a distinction between definite and indefinite relative clauses in Coyulta (see (101) and (102) above is also well-worth looking into, particularly given the typological work linking interrogative and indefinite forms in other languages (Ultan 1978; Haspelmath 1997; Bhat 2000, 2004). It is to be hoped that the findings presented in this paper will be an incentive for further investigation into relative and subordinate clauses in the Totonacan family, and that this work in turn will improve our understanding of relativization and its diachronic development in these and other languages of the world.

\section{References}

Andersen, Gerry. 2012. Totonaco del Cerro Xinolatépetl. In Levy and Beck (2012), 181-193.

Aschmann, Elizabeth D. 1984. The relative clause in Highland Totonac. SIL Mexico Workpapers $6,1-27$.

Aschmann, Herman P. 1983. Vocabulario totonaco de la sierra. Mexico City: Summer Insititute of Linguistics.

Aschmann, Herman P. n.d.a Shoebox lexical database for Zapotitlán de Méndez Totonac. In possession of the author.

Aschmann, Herman P. n.d.b Shoebox lexical database for Coyutla Totonac. In possession of the author.

Beck, David. 2004. Upper Necaxa Totonac. Berlin: LINCOM Europa.

Beck, David. 2008. Ideophones, adverbs, and predicate qualification in Upper Necaxa Totonac. International Journal of American Linguistics 74. 1-46.

Beck, David. 2016. Uniqueness and grammatical relations in Upper Necaxa Totonac. Linguistics 54, 59-118. 
Bhat, Darbhe Narayana Shankara. 2000. The Indefinite-interrogative puzzle. Linguistic Typology 4. 365-400.

Bhat, Darbhe Narayana Shankara. 2004. Pronouns. Oxford: Oxford University Press.

Brown, Cecil H., David Beck, Grzegorz Kondrak, James K. Watters, and Søren Wichmann. 2011. Totozoquean. International Journal of American Linguistics 77. 323-372.

Brown, Cecil H., Søren Wichmann, and David Beck. 2014. Chitimacha: A Mesoamerican language in the Lower Mississippi Valley. International Journal of American Linguistics 80. 425-474.

Comrie, Bernard and Tania Kuteva. 2013. Relativization strategies. The World Atlas of Language Structures Online, ed. by Matthew S. Dryer and Martin Haspelmath. Leipzig: Max Planck Institute for Evolutionary Anthropology. (http://wals.info/chapter/s8, accessed 2015-09-14.)

Cole, Peter. 1987. The structure of internally-headed relative clauses. Natural Language and Linguistic Theory 5. 277-302.

Davletshin, Albert. 2008. Classification of the Totonacan languages. Presented at Problemy izučenij dal'nego rodstva jazykov (k 55-leti C. A. Starostina), Russian State University for the Humanities, Moscow, March 25-28.

de Vries, Mark. 2005. The fall and rise of universals on relativization. Journal of Universal Language 6. 1-33.

Dryer, Matthew S. 1986. Primary objects, secondary objects, and anti-dative. Language 62. 808845.

Dryer, Matthew S. 1997. On the six-way word order typology. Studies in Language 21. 69-103.

Dryer, Matthew S. 2013. Order of relative clause and noun. The World Atlas of Language Structures Online, ed. by Matthew S. Dryer and Martin Haspelmath. Leipzig: Max Planck Institute for Evolutionary Anthropology. (http://wals.info/chapter/90, accessed 2015-09-13)

García Rojas, Blanca. 1978. Dialectología de la zona totonaco-tepehua. Honors thesis, Escuela Nacional de Antropología e Historia, Mexico.

Haegeman, Liliane, and Marjo van Koppen. 2012. Complementizer agreement and the relation between $\mathrm{C}^{0}$ and $\mathrm{T}^{0}$. Linguistic Inquiry 43. 441-454

Haspelmath, Martin. 1997. Indefinite Pronouns. Oxford: Oxford University Press.

Ichon, Alain. 1969. La religión de los totonacos de la sierra. Mexico City: Instituto Nacional Indigenista.

Instituto Nacional de Estadística y Geografía (INEGI). 2010. Censo de Población y Vivienda de 2010. (http://www.inegi.org.mx/est/contenidos/proyectos/ccpv/cpv2010/Default.aspx, accessed 2011-12-21.)

Keenan, Edward L., and Bernard Comrie. 1977. Noun phrase accessibility and Universal Grammar. Linguistic Inquiry 8. 63-99.

Levy, Paulette. 1990. Totonaco de Papantla, Veracruz. Mexico City: El Colegio de México.

Levy, Paulette. 2002. El aplicativo dativo/benefactivo en totonaco de Papantla. Memorias del VI Encuentro Internacional de Lingüística del Noroeste: Memorias Tomo 1, ed by Zarina Estrada Fernández and Rosa María Ortíz Ciscomani, 445-60. Hermosillo: Universidad de Sonora.

Levy, Paulette. 2012. Totonaco de Papantla. In Levy and Beck (2012), 345-466.

Levy, Paulette, and David Beck. (eds.) 2012. Las lenguas totonacas y tepehuas: Textos y materiales para su estudio. Mexico City: UNAM. 
Lewis, Robert E., Jr. 2013. Complementizer agreement in Najdi Arabic. MA thesis, University of Kansas.

MacKay, Carolyn J. 1999. A grammar of Misantla Totonac. Salt Lake City: University of Utah Press.

MacKay, Carolyn J., and Frank R. Trechsel. 2005. Totonaco de Misantla, Veracruz. Archivo de lenguas indígenas de México, 26. Mexico City: El Colegio de México.

MacKay, Carolyn J., and Frank R. Trechsel. 2008. Symmetrical objects in Misantla Totonac. International Journal of American Linguistics 74. 227-55.

MacKay, Carolyn J., and Frank R. Trechsel. 2010. Tepehua de Pisaflores, Veracruz. Mexico City: El Colegio de México

MacKay, Carolyn J., and Frank R. Trechsel. 2012a. Tepehua de Pisaflores. In Levy and Beck (2012), 107-118.

MacKay, Carolyn J., and Frank R. Trechsel. 2012b. Totonaco de Misantla, Veracruz. In Levy and Beck (2012), 119-179.

MacKay, Carolyn J., and Frank R. Trechsel. 2014. Diagnósticos morfológicos para la clasificación de las lenguas totonaco-tepehua. Lenguas, estructuras y hablantes: Estudios en homenaje a Thomas C. Smith-Stark, vol. 2, ed. by Rebeca Barriga Villanueva and Esther Herrera Zendejas, 843-870. Mexico City: El Colegio de México.

MacKay, Carolyn J., and Frank R. Trechsel. 2015. Totonac-Tepehua genetic relationships. Amerindia 37. 121-158.

McFarland, Teresa Ann. 2009. The phonology and morphology of Filomeno Mata Totonac. PhD dissertation, University of California, Berkeley.

McFarland, Teresa. 2012. Totonaco de Filomeno Mata. In Levy and Beck (2012), 269-291.

McQuown, Norman A. 1990. Gramática de la lengua totonaca. Coatepec, Sierra Norte de Puebla. Mexico City: UNAM.

Mel'čuk, Igor A. 2001. Communicative Organization in Natural Language: The SemanticCommunicative Structure of sentences. Amsterdam: John Benjamins.

Moore, Devin. 2016. Relative clauses in Coahuitlán Totonac. Oklahoma Working Papers in Indigenous Languages 2:22-40.

Nichols, Johanna. 1986. Head-marking and dependent-marking grammar. Language 62. 56-119.

Reid, Aileen A. 1991 Gramática totonaca de Xicotepec de Juárez. Mexico City: Summer Institute of Linguistics.

Reid, Aileen A., Ruth G. Bishop, and Ella M. Button. n.d. Shoebox lexical database for Apapantilla Totonac. In possession of the author.

Reid, Aileen A., Ruth G. Bishop, Ella M. Button, and Robert E. Longacre. 1968. Totonac: From clause to discourse. Norman, OK: Summer Institute of Linguistics.

Román Lobato, Gabriela. 2008. La juntura fonológica en el totonaco de Ozelonacaxtla, Huehuetla, Puebla. MA thesis, Centro de Investigaciones y Estudios Superiores en Antropología Social.

Román Lobato, Gabriela. 2012. Totonaco de San Juan Ozelonacaxtla, Puebla. In Levy and Beck (2012), 321-344.

Smythe Kung, Susan. 2007. A descriptive grammar of Huehuetla Tepehua. PhD dissertation, UT Austin.

Smythe Kung, Susan. 2012. Tepehua de Huehuetla. In Levy and Beck (2012), 65-106.

Tino, Jorge. 2012. Totonaco de Olintla. In Levy and Beck (2012), 293-319. 
Troiani, Duna. 2004. Aperçu grammatical du totonaque de Huehuetla, Puebla, Mexique. Berlin: LINCOM Europa.

Ultan, Russell. 1978. Some general characteristics of interrogative systems. Universals of Human Language, iv: Syntax, ed. by Joseph H. Greenberg, Charles A. Ferguson, and Edith A. Moravcsik, 211-248. Stanford, CA: Stanford University Press.

Vallduví, Enric. 1992. The Informational Component. New York: Garland.

Watters, James K. 1988. Topics in Tepehua grammar. PhD. dissertation, UC Berkeley.

Watters, James K. 1989. The syntax of applicatives in Tepehua (Totonacan). Ms., Summer Institute of Linguistics. http://www.sil.org/system/files/reapdata/97/71/32/ 977132796476 81177365240258472297233424/SyntApplicTepehua.pdf (accessed 3 February 2015).

Watters, James K. 2012. Tepehua de Tlachichilco. In Levy and Beck (2012), 43-64.

Watters, James K. n.d. Tlachichilco Tepehua lexicon. In possession of the author.

Zwart, Jan-Wouter. 1993. Verb movement and complementizer agreement. MIT Working Papers in Linguistics 18. Papers on case and agreement I. 281-296.

Zwart, Jan-Wouter. 2006. Complementizer agreement and dependency marking typology. Leiden Working Papers in Linguistics 3. 53-72. 